\title{
Solanesol Mediated SIRT-1 Signaling Activation Prevents Neurobehavioral and Neurochemical Defects in Ouabain-induced Experimental Model of Bipolar Disorder in Rats
}

\section{Bidisha Rajkhowa}

Indo Soviet Friendship College of Pharmacy

Sidharth Mehan ( $\nabla$ sidh.mehan@gmail.com )

ISF College of Pinharmacy, Moga, Punjab, India https://orcid.org/0000-0003-0034-835X

\section{Research Article}

Keywords: Bipolar disorder, Ouabain, SIRT-1, Solanesol, Lithium, Neurotransmitter, Neuroprotection

Posted Date: August 2nd, 2021

DOI: https://doi.org/10.21203/rs.3.rs-735926/v1

License: (c) (1) This work is licensed under a Creative Commons Attribution 4.0 International License.

Read Full License 


\section{Abstract}

Bipolar disorder (BD) is a serious and widespread chronic mental condition characterized by mood swings ranging from depressive lows to manic highs. Several studies have linked SIRT-1 (silent mating type information regulation-2 homologs) signalling downregulation to the progression of $\mathrm{BD}$ and other neurological dysfunctions. The purpose of this study was to investigate the neuroprotective potential of solanesol(SNL) in rats with brain intoxication caused by intracerebroventricular (ICV) injections of ouabain(OUA), with a particular focus on its influence on the SIRT-1 signaling activator in the brain. The goal of this study was to investigate the neuroprotective potential of Solanesol (SNL) in rats treated with ICV-OUA injection, with a special emphasis on its effect on the SIRT-1 signalling activation in the brain. Ouabain (OUA) is a cardiac glycoside that inhibits the Na+/K+-ATPase (sodium-potassium adenosine triphosphatase). SNL is an active phytoconstituent belongs to the Solanaceae family, derived from the plant Nicotiana tabacum. SNL is employed as a precursor for the production of CoQ10 (Coenzyme Q10), which has potent antioxidant and neuroprotective properties. Lithium (Li), an important mood stabiliser drug employed as a control in the present study. This study looked at the neuroprotective potential of SNL at doses of 40 and $80 \mathrm{mg} / \mathrm{kg}$ in ICV-OUA injections, which caused BD-like neurobehavioral deficits in Wistar rats. Wistar rats were divided into eight groups $(n=8)$ and given 1 $\mathrm{mM} / 0.5$ I OUA injections for three days. Long-term SNL and lithium administration can reduce the number of rearing and crossings and time spent in the centre, locomotive activity, and immobility time. According to the findings of this study, SNL increases the levels of SIRT-1 in CSF, blood plasma, and brain homogenate samples. In addition, SNL modulates the apoptotic markers like Caspase-3, Bax (proapoptotic), and Bcl-2 (anti-apoptotic) in rat brain homogenates and blood plasma samples. Mitochondrial-ETC complexes enzymes including complex-I, II, IV, V, and CoQ10 were also resorted after the long term administration of SNL. Furthermore, SNL reduced inflammatory cytokines (TNF-a, IL-1 $\beta$ ) while restoring neurotransmitter (serotonin, dopamine, glutamate, and acetylcholine) levels and level of oxidative stress markers. Our neurochemical observations could be validated as diagnostic biomarkers in BD-like conditions. As a result, SNL as SIRT-1 signaling activator could be a promising therapeutic target for the treatment of BD.

\subsection{Introduction}

BD is a severe mental illness typified by depression, mania, psychosis, and neurocognitive deficits (Waddington et al., 2021; McCarthy et al., 2014). It is one of the ten most debilitating psychiatric disorders globally (Rhee et al., 2020). Based upon family and twin studies, a genetic basis of the illness is strongly suspected, but the genes responsible for BD remain primarily unknown (McGuffin et al., 2003). It is a heritable mental illness with complex etiology (Uher and Zwicker, 2017), linked to an increased risk of morbidity, mortality, and comorbidity in psychiatry (Serra et al., 2017; Mullins et al., 2021). BD affects individuals from a young age and is related to physical morbidity and early death (Walker et al., 2015).

$\mathrm{BD}$ is uncommon among medical diseases in that its manifestations alternate between two distinct (Hirschfeld et al., 2014). These key characteristics are met 
by the experimental animal model of mania induced by OUA, a Na+/K+-ATPase enzyme inhibitor, making it suitable for studying numerous behavioural and neurochemical aspects of BD (Jornada et al., 2011). OUA dose-dependently increases locomotor activity in rats, associated with manic-like behavior (Valvassori et al., 2015). The Na+/K+-ATPase is an ion transporter that influences neuronal excitability, electrochemical gradient, resting membrane potential, and neurotransmitter release and uptake, in addition to maintaining $\mathrm{Na}+/ \mathrm{K}+$ equilibrium (Ladol and Sharma et al., 2021). According to reports, the validity of animal models in psychiatric diseases should identify the three basic criteria: face validity, construct validity, and predictive validity (Nestler and Hyman, 2011). Face validity refers to a model's ability to reproduce the symptoms of a particular condition. On the other hand, construct validity relates to the model's ability to recreate some pathophysiological components of the disease. Finally, predictive validity examines if the medications used to treat a disorder can reverse the symptoms observed in the animal model (Valvassori et al., 2013). Furthermore, ICV injection of OUA into rats results in neurochemical changes similar to those reported in BD patients and abnormalities in neurotrophic factors, mitochondrial function and causes oxidative stress (Lopes-Borges et al., 2015).

SIRT-1 is a protein found in the adult brain and spinal cord, specifically the amygdala, hippocampus, cerebellum, hypothalamus, and deeper into the neuronal body (Schwartz et al., 2000; Michan and Sinclair., 2007). SIRT-1 is a transcription factor that regulates stress response, genome maintenance, axon elongation, dendritic branching, and endocrine activity (Li et al., 2013). SIRT-1 participates in several functions, including transcription, metabolism, genome maintenance, neural progenitor fates, axon elongation, dendritic branching, and endocrine function (Herskovits and Guarente, 2014; Donmez et al., 2013).

Deacetylation of this protein affects cellular processes like aging, inflammation, apoptosis, mitochondrial biogenesis, and stress resistance (Aguirre et al., 2015; Alcendor et al., 2007).

SIRT-1 deficiency results in hyperglycemia and osteoporosis (Bartoli-Leonard et al., 2019). SIRT-1 dysregulation promotes disease progression by increasing oxidative damage and inflammation (Elibol and Kilic et al., 2018). In a recent study, SIRT-1 overexpression was demonstrated to increase cell survival, decrease cell apoptosis, and reduce the release of pro-inflammatory cytokines (Li et al., 2018). SIRT-1 also influences metabolism and longevity by regulating the production of hypothalamic peptide hormones (Nillni et al., 2016). SIRT-1 specificity increases in essential metabolic pathways in hypothalamic circuits, linked to alterations in SIRT-1 downstream factors such as FoxO transcription factors (Baldo et al., 2018). In light of these facts, we reviewed recent studies concerning the relationship between increasing SIRT-1 protein levels rather than reducing SIRT-1 expression and regulating several disease-related states such as obesity, cardiovascular disease, and neurodegeneration. SIRT-1 deficiency affects transcription factors (p53, PGC-1, NF-B, and FOXO) as well as molecular changes such as gene expression, influencing brain plasticity, Th17 cell inhibition, and interleukin-1 production (Lee et al., 2016; Zhong et al., 2012).

SIRT-1 activation appears to have beneficial effects in BD (Alageel et al., 2018), MS (Zhao et al., 2015), Parkincnn's diceace (PD) (Fenn et al 2015) and Alzheimer's disease (AD) (Donmez et al., 2013). Recent Loading [MathJax]/jax/output/CommonHTML/jax.js 
research has revealed a link between SIRT-1 downregulation and disease progression, as well as an increase in oxidative stress and inflammation (Singh et al., 2017). Patients with obesity experienced higher fatty acid oxidation due to a considerable decrease in SIRT-1 levels, which were linked to increased oxidative stress (Elibol and Kilic et al., 2018).

SIRT-1 downregulation has been linked to a depressive phase in humans (Zhou et al., 2020). According to Abe-Higuchi et al., continuous stress decreases SIRT-1 activity in the dentate gyrus, and pharmacological or genetic elimination of hippocampus SIRT-1 increases depression-like behaviours. Chronic stress may result in the formation of depression-related phenotypes and aberrant dendritic structures, which could be prevented by activating SIRT-1. In a mouse model of chronic stress-induced depression, researchers also investigated the involvement of extracellular signal-regulated protein kinases 1 and 2 (ERK1/2) as potential downstream targets of SIRT-1. It was observed that activating hippocampus SIRT-1 increased ERK1/2 phosphorylation under stressed conditions and that viral-modulated hippocampal ERK2 function was related to antidepressive and depressed behaviours (Abe-Higuchi et al., 2016). Another research reveals that chronic variable stress (CVS) increased depressive-like behaviour, which was linked to a decrease in ERK1/2 phosphorylation, Bcl-2 expression, and H4 (K12) acetylation in hippocampal subregions following chronic stress (Ferland et al., 2013). SIRT-1 deficiency enhanced dopamine neurotransmission, which is involved in developing bipolar disorder manic-likeee episodes (Zhu et al., 2019).

SNL is a solanaceous crop produced by the 'Nicotiana Tobacco' from the Solanaceae family.SNL is a long-chain polyisoprenoid alcohol molecule that contains nine isoprene units and is also recognized as a CoQ10 precursor (Rajdev et al., 2020). CoQ10 (2, 3 dimethoxy-5-methyl-6-decaprenyl benzoquinone) is the most prevalent coenzyme in human mitochondria, with ten repeating isoprene units. It is also known as ubiquinone. CoQ10 is a component of the electron transport chain that accepts an electron from complex-I and pumps protons across the inner mitochondrial membrane before passing the electrons to complex-II, responsible for the generation of ATP. It reduces oxidative damage to neurons and improves behavioural function in animals (Sharma et al., 2019).

SNL is used to treat ulcers and has a variety of pharmacological effects, including antibacterial, antiinflammatory, and anti-tumor activities. In the pharmaceutical sector, it is used to produce coenzyme Q10, vitamin K2, and N-solanesyl-N, N'-bis(3,4-dimethoxybenzyl) ethylenediamine (SDB) (Yan et al., 2015).

Amyotrophic lateral sclerosis (ALS) (Alam et al., 2020) and multiple sclerosis (MS) are two other neurodegenerative disorders that potentially benefit from SNL treatment (Sharma et al., 2021). CoQ10 precursors have been shown to protect against migraine (Sandor et al., 2005) and Huntington's disease (Mehan et al., 2018). CoQ10 precursors have been shown to prevention against neurodegenerative diseases such as Parkinson's disease (Shults et al., 2004) and amyotrophic lateral sclerosis (ALS) (Matthews et al., 1998). It has also been effective in Alzheimer's disease, multiple sclerosis (DeLegge and Smoke, 2008), and bipolar disorder (BD) (Forester et al., 2015). In addition to its anti-oxidant and antianin n nronerties it is cunnnced tn hnnct the body's immune system and improve cognitive function (Guo Loading [MathJax]/jax/output/CommonHTML/jax.js 
et al., 2008). CoQ10 has also been demonstrated to protect against hepatic IR injury via modulating the SIRT-1 pathway (Mahmoud et al., 2019).

As a SIRT-1 signalling activator, SNL has been shown to have neuroprotective properties against Alzheimer's disease (Jaiswal et al., 2019), intracerebral haemorrhage (ICH) (Rajdev et al., 2020), and autism (Sharma et al., 2019). It also has neuroprotective benefits against MS (Sharma et al., 2021) and HD (Mehan et al., 2010).

Lithium (Li), an important mood stabilizer, effectively prevents such behavioural changes (Jornada et al., 2011).On the other hand, hypoactivity is insufficient to imitate a state of depression, and more research is required to support this hypothesis. The "Na+/K+-ATPase hypothesis," which suggests that decreased enzyme activity has a crucial role in the onset of manic and depressed mood episodes in BD, was used to build the OUA model of mania (El-Mallakh and Wyatt, 1995). Several studies have found that the activity of the $\mathrm{Na}+/ \mathrm{K}+-$ ATPase is reduced in bipolar patients (Banerjee et al., 2012; El-Mallakh et al., 1983).

The mood-stabilizing therapeutic effects of lithium were just identified in the absence of any relevant mechanistic knowledge of BD (Can et al., 2014). Current medications, such as lithium alone or in combination, are successful in 60 percent of continuously treated individuals (Pisanu et al., 2018). Although olanzapine, quetiapine, and ziprasidone (Monti, 2016), as well as valproate, carbamazepine, and lamotrigine (Joas et al., 2017), are generally valuable for reversing manic episodes and preventing future events. However, they are of little, if any, use in the acute treatment of depressive episodes. Furthermore, conventional antidepressants, whether administered alone or in combination with mood stabilizers or antipsychotics, are generally ineffective for treating depressive episodes and may encourage mood flipping in a group of people with BD (Mclnerney and Kennedy, 2014).

In this investigation, we hypothesized that the SNL could upregulate SIRT-1 target signaling mechanisms and, as a result, can alleviate neuropathological changes in OUA-induced BD-like rats through its putative target-modulating properties. Furthermore, SNL could be employed in combination with other standard drug regimens to provide a promising pharmacological strategy for people suffering from neuropsychiatric illnesses such as BD. As a result of these promising pharmacological effects, we investigated and evaluated SNL's neuroprotective profile in rat brain homogenate, blood plasma, and CSF samples, with the goal of using these biological samples as effective and provable diagnostic biomarkers during the early stages of neurodegeneration and neuropsychiatric disorders.

\subsection{Material And Methods}

\subsection{Experimental animals}

Adult Wistar rats (220-250gm, nine weeks of age, either sex) were collected from the ISF College of Pharmacy Central Animal House in Moga, Punjab. These animals were evenly divided and housed in polyacrylic cages with a wire mesh top and soft bedding under typical husbandry circumstances of a 12Loading [MathJax]/jax/output/CommonHTML/jax.js and water, and a temperature of $23 \pm 2^{\circ} \mathrm{C}$. According to the 
requirements of the Government of India, the experimental procedure was approved by the Institutional AnimalEthics Committee (IAEC) with a registration number.816/PO/ReBiBt/S/04/CPCSEA as protocol no. ISFCP/IAEC/CPCSEA/Meeting No: 28/2020/Protocol No.463. Animals were acclimatized to laboratory conditions before being used in experiments.

\subsection{Drugs and chemicals}

OUA was purchased from Sigma-Aldrich (USA). Ex-gratia samples of SNL from BAPEX (India) and Lithium carbonate from Sun Pharma were provided. All of the other chemicals employed in the experiment were of analytical grade. Before use, the medication and chemical solutions were freshly made. Oral administration of SNL dissolved in water (with 2\% ethanol) (p.o.) (Mehan et al., 2017).

\subsection{Experimental animal grouping}

A total of 48 Wistar rats (either sex), nine weeks old, were employed during the course of the 28-day protocol schedule. These rats were kept in a polyacrylic cage with a wire mesh top and soft bedding (38 $\mathrm{cm} 32 \mathrm{~cm} 16 \mathrm{~cm} ; 3-4$ rats per cage) at a regulated temperature $\left(22^{\circ} \mathrm{C} \pm 2^{\circ} \mathrm{C}\right)$ and humidity $(65-70 \%)$ with artificial illumination ( $12 \mathrm{~h} / 12 \mathrm{~h}$ light/dark cycle, lights on at 6:00 AM). Their bedding consisted of residue-free wood shavings that had been sanitized. These animals had unrestricted access to a standard chow diet as well as purified water. To avoid the effects of the circadian rhythm, the entire experimental protocol schedule was completed between 9:00 AM and 1:00 PM. They were randomly divided into eight groups ( $\mathrm{n}=6$ per group). Group 1 vehicle control; Group 2 Sham control; Group 3 SNL perse (80mg/kg p.o.); Group 4 OUA ( $1 \mathrm{mM} / 0.5 \mu \mathrm{l} / 5 \mathrm{~min} /$ Unilateral/ICV injection); Group 5 OUA + SNL (40mg/kg, p.o.); Group 6 OUA + SNL (80mg/kg p.o.); Group 7 OUA + Li (60mg/kg, i.p), and Group 8 OUA + $\mathrm{Li}+\mathrm{SNL80}$. From the first to the 28th day, several behavioral parameters (Forced swim test, Open field test, Locomotor activity) were measured. The 28th day was marked by collecting biological samples (CSF and blood plasma) from Wistar adult rats. The animals were fully anesthetized with sodium pentobarbital $(270 \mathrm{mg} / \mathrm{mL}$, i.p.), and then fresh brains were preserved in ice-cold PBS (0.1 M) of PBS for further biochemical evaluation. The biochemical estimation of SIRT-1 level determination in brain homogenate, blood plasma, and CSF was performed on the 29th and 30th days. Oxidative indicators (AChE, LDH, MDA, GSH, SOD, Nitrite) were also measured in brain homogenates. Similarly, apoptotic markers (Caspase-3, Bax, Bcl-2) and mitochondrial ETC-complexes enzymes (Complex-I, II, IV, V, and CoQ10) in the brain homogenate and blood plasma were also examined. Inflammatory markers (IL-1, TNF-) and neurotransmitters (Ach, Dopamine, 5-HT, Glutamate) were also measured in brain homogenate and blood plasma. The protocol for the experiment is summarized in (Fig. 1).

\subsection{ICV-OUA induced experimental animal model of BD}

The OUA-induced BD experimental model in rats was established using a well-known method (Valvassori et al., 2019). Three days of OUA-ICV injection $(1 \mathrm{mM} / 0.5 \mu \mathrm{l})$ were given to the rats in the experiment. According to Valvassori et al., OUA generates neurological damage similar to that shown in an experimental animal model of BD. It is a valid model for examining pathophysiological alterations similar 
The rats were habituated to the laboratory environment. After acclimatization, all animals in the experimental groups were anesthetized with ketamine $(75 \mathrm{mg} / \mathrm{kg}$, i.p.) before being placed in a stereotaxic frame (Sharma et al., 2021). After shaving the head and cutting a midline scalp incision, the skull was exposed. With the tooth bar set at $0 \mathrm{~mm}$, each animal skin overlying the skull, as well as the coordinates for the striatum, must be precisely measured (AP-1.0mm; ML-2.5mm; DV-3.5mm) (Valvassori et al., 2019). Then, according to the protocol schedule, all animals in the experimental groups received OUA ( $1 \mathrm{mM} / 0.5 \mu \mathrm{l} / 5 \mathrm{~min} /$ Unilateral/ICV injection) for three days (1 $\mathrm{st}, 3 \mathrm{rd}$, and 7 th days). The infusion was administered manually, using a Hamilton syringe, through the burr holes drilled onto the skull surface. The injection rate in the experimental groups was $0.5 \mu \mathrm{l} / 5 \mathrm{~min}$, with the needle remaining in place for a further 1 minute before being progressively removed. The cannula is sealed with a detachable plastic ear pin. Before being sutured with an absorbable surgical suture connected to a sterile surgical needle, the hole was filled with dental cement.

Rats were housed individually in a polyacrylic cage that usually contained a warm cloth for postoperative care. Special attention was given to them until they regained spontaneous movement, which usually occurred 2-3 hours after anesthesia. The temperature in the room was kept at $25 \pm 3^{\circ} \mathrm{C}$. To avoid physical trauma after surgery, milk and glucose water were kept in the cages for 2-3 days. Gentamycin (35 mg/kg) was given intraperitoneally to rats for three days to prevent sepsis, and lignocaine gel was applied to the sutured area to relieve pain. Neosporin powder was dusted on them to prevent bacterial infection of the skin. Following surgery, the general health of the body and clinical symptoms such as dehydration were closely examined.

After seven days, rats continued to eat healthy food and drink plenty of water, and their spontaneous mobility returned, indicating that they had healed. The protocol drug SNL at 40 and $80 \mathrm{mg}$ and the standard drug Lithium alone and Lithium in combination with SNL80 mg/kg were administered chronically beginning on day 8th and continuing until day 28th. Behavioral parameters such as locomotor activity, open field test, and force swim test were carried out in accordance with the protocol schedule. After completing the protocol schedule, all animals were decapitated on days 29th and 30th, and their brains were removed to perform biochemical, inflammatory, and neurochemical assessments(Valvassor et al., 2021).

\subsection{Parameters assessed}

\section{Measurement of body weight}

According to the protocol schedule, body weight was measured on the 1st, 7th, 14th, 21 st, and 28th days of the experiment (Valvassori et al., 2019.

Assessment of behavioral parameters

Open field test (OFT) 
The animals exhibited manic-like behaviour after a single injection of OUA for three days (1st, 3rd, and 7th). The rat was placed in a cage on the first day and trained to explore an open field for 5 minutes. During the test, a camera monitored each rat's activities, including an increase in the number of crossings, rearings, and time spent in the centre. According to the protocol schedule, on days $1 \mathrm{st}, 7 \mathrm{th}, 14 \mathrm{th}, 21 \mathrm{st}$, and 28th, an open field test was used to measure the number of crossings, rearings, and time spent in the centre in rats (Kumar et al., 2021).

\section{Locomotor activity}

Increased locomotor activity is a sign of manic-like behaviour (Nestler and Hyman 2010). The device uses photocells to detect motor activity. The animals were placed in the activity room for 3 minutes prior to the recording for habituation. On the 1st, 9th, 18th, and 27th days after ICV administrations, locomotion was assessed using an actophotometer (INCO (Instruments and Chemicals Private Limited), Haryana) for 5 minutes, and values were represented as counts per 5 minutes (Rahi et al., 2021).

\section{Forced swimming test (FST)}

A force swim test was used to evaluate the immobility time. Individual rats were placed in cylindrical tanks (height $50 \mathrm{~cm}$; diameter $15 \mathrm{~cm}$ ) with $30 \mathrm{~cm}$ of water at a temperature of $24 \pm 1^{\circ} \mathrm{C}$. A camera filmed the rat's movements for 5 minutes. During the training session, rats are exposed to the tank for 15 minutes on the first day and 5 minutes on the second day. The testing period for rats consists of a single 6-minute exposure, with the first 2 minutes serving as a habituation period. Each animal was tested for its depressive-like behaviour on days $1 \mathrm{st}$, 9th, 18th, and 27th following ICV injection. The immobility time was recorded for 5 minutes during each session. When the rat stopped struggling and stayed motionless in an upright position in the water, only making slight movements to keep its head above the water, it was determined to be immobile (Rahi et al., 2021).

\section{Neurochemical alterations evaluation}

\section{Collection and preparation of biological samples}

On day 29th of the experiment, $2.5 \mathrm{ml}$ of blood was collected from anesthetized rats through retro-bulbar puncture from the orbital venous plexus by inserting a capillary tube medially into the rat eye. Blood from the plexus was collected into a sterile Eppendorf tube via the capillary action through gentle rotation and retraction of the tube (Boynton et al., 2020). The blood samples were then centrifuged at 10,000 $\mathrm{xg}$ for 15 minutes to separate the plasma, and the supernatant was carefully stored in a deep freeze (at $-80 \mathrm{o} C)$ for further use.

Following blood collection, rats were deeply anesthetized with sodium pentobarbital $(270 \mathrm{mg} / \mathrm{ml}$, i.p.) and subjected to caudal incision, translucent duramater was exposed, and a 30 gauge needle was gently placed at 30囚 angle into the cisterna magna (Pegg et al., 2010). Approximately $100 \mu \mathrm{L} \mathrm{CSF}$ was carefully ejected into a $0.5 \mathrm{ml}$ sterile Eppendorf tube using the suction pressure of a $1 \mathrm{ml}$ tuberculin syringe 
Immediately after CSF collection, rats were sacrificed by decapitation; whole brains were isolated from the skull with the utmost care, freshly weighed and washed with ice-cold, isotonic saline solution, and then homogenized with $0.1 \mathrm{M}(\mathrm{w} / \mathrm{v})$ of chilled PBS $(\mathrm{pH}=7.4)$. The rat brain homogenate was then centrifuged at $10,000 \times \mathrm{g}$ for 15 minutes, the supernatant was separated, and the aliquots were preserved. The samples were deep-freezed at $-80^{\circ} \mathrm{C}$ to be used as and when required for various biochemical estimations.

\section{Assessment of cellular and molecular markers}

\section{Measurement of SIRT-1 protein level}

The level of SIRT-1 protein expression was measured using standard ELISA kits (E Lab Science, China). This test was carried out in the brain homogenate (Kumar et al., 2021), blood plasma (Wu et al., 2012), and CSF (David et al., 2015)according to the standard technique. The values are given in brain homogenate as $\mathrm{nM} / \mu \mathrm{g}$ protein (Minj et al., 2021) and as $\mathrm{ng} / \mathrm{ml}$ protein in blood plasma (Mariani et al., 2018) and CSF (Jamali-Raeufy et al., 2020).

\section{Assessment of apoptotic markers}

\section{Measurement of caspase-3 level}

Caspase-3 concentrations were determined using commercial ELISA kits (E Lab Science, China). ELISA kits were used to perform this test in brain homogenate (Rahi et al., 2021) and blood plasma (Guo et al., 2018).

\section{Measurement of Bax and Bcl-2 levels}

Commercial ELISA kits were used to determine the protein levels of Bax and Bcl-2 (E Lab Science, China). The level of Bax protein in brain homogenate (Tiwari et al., 2021) and blood plasma was measured (Wang et al., 2018). Using ELISA commercial kits, the quantities of anti-apoptotic proteins such as Bcl-2 were evaluated in brain homogenate (Sharma et al., 2019) and blood plasma (Wang et al., 2018). (Elabsciences, China).

\section{Assessment of mitochondrial ETC-complexes enzyme levels}

Preparation of Post mitochondrial supernatant (PMS) from rat whole-brain homogenate

The rat whole brain homogenate was centrifuged for 20 minutes at $5000 \mathrm{rpm}$ at $4^{\circ} \mathrm{C}$, and the resulting supernatant was used as rat brain PMS for further research. Differential centrifugation was used to prepare the crude mitochondrial fraction. By gently shaking at $4^{\circ} \mathrm{C}$ for 60 minutes, the pellet generated during the preparation of PMS was combined with $0.1 \mathrm{M}$ sodium phosphate buffer $(\mathrm{pH} 7.4)$ in a 1:10 proportion. The pellets were re-suspended in the same buffer containing extra sucrose at a concentration of $250 \mathrm{mmol} / \mathrm{L}$ after centrifugation at $16000 \mathrm{rpm}$ at $0^{\circ} \mathrm{C}$ for 30 minutes. The centrifugation and 
resuspension steps were done three times, and the crude mitochondrial fraction produced in the buffered sucrose solution was used for further investigation (Sharma et al., 2021; Rana et al., 2019).

Mitochondrial ETC complex-I enzyme activity (NADPH dehydrogenase)

To determine complex-I activity, the rate of NADH oxidation at $340 \mathrm{~nm}$ in an assay medium was measured spectrophotometrically at $37^{\circ} \mathrm{C}$ for 3 minutes. In the absence and presence of $2 \mu \mathrm{M}$ rotenone, reactions were carried out, and the rotenone-sensitive activity was assigned to complex-I (Sharma et al., 2021; Mehan et al., 2020).

\section{Mitochondrial ETC complex-Il enzyme activity(Succinatedehydrogenase/SDH)}

At $490 \mathrm{~nm}$ (Shimadzu, UV-1700), the absorbance of a $0.3 \mathrm{~mL}$ sodium succinate solution in a $50 \mu$ gradient fraction of homogenate was measured. The molar extinction coefficient of the chromophore $(1.36 \times 104$ $M-1 \mathrm{~cm}-1$ ) was used to determine the results, which were reported as INT decreased $\mu \mathrm{mol} / \mathrm{mg}$ protein (Sharma et al., 2021; Kapoor et al., 2019).

\section{Mitochondrial ETC complex-IV enzyme activity (cytochrome oxidase)}

Reduced cytochrome-C ( $0.3 \mathrm{mM})$ was added to the assay mixture in a $75 \mathrm{mM}$ phosphate buffer. The process was started by adding a solubilized mitochondrial sample, and the absorbance change was measured for 2 minutes at $550 \mathrm{~nm}$ (Sharma et al., 2021; Alam et al., 2019).

\section{Mitochondrial ETC complex-V enzyme activity (ATP synthase)}

To inactivate the ATPases, aliquots of homogenates were sonicated immediately in ice-cold perchloric acid $(0.1 \mathrm{~N})$. Supernatants containing ATP were neutralized with $1 \mathrm{~N} \mathrm{NaOH}$ and kept at $-80^{\circ} \mathrm{C}$ until analysis after centrifugation $\left(14.000 \mathrm{~g}, 4^{\circ} \mathrm{C}\right.$, and $\left.5 \mathrm{~min}\right)$. A reverse-phase HPLC was used to measure the amount of ATP in the supernatants (PerkinElmer). The reference solution of ATP was made according to the dissolving standard, and the detecting wavelength was $254 \mathrm{~nm}$ (Sharma et al., 2021; Dudi et al., 2018).

\section{Assessment of neurotransmitters levels}

\section{Measurement of brain serotonin levels}

The level of serotonin in brain homogenate was estimated using the method of Sharma et al. with minor modifications. HPLC with an electrochemical detector and a C18 reverse-phase column was used to determine it. Sodium citrate buffer $(\mathrm{pH} 4.5)$ - acetonitrile $(87: 13, \mathrm{v} / \mathrm{v})$ is used in the mobile phase. Ten $\mathrm{mmol} / \mathrm{L}$ citric acid, $25 \mathrm{mmol} / \mathrm{L} \mathrm{NaH} 2 \mathrm{HPO} 4,25 \mathrm{mmol} / \mathrm{L}$ EDTA, and two mmol/L 1- heptane sulfonic acid made up the sodium citrate buffer. The electrochemical parameters in the experiments were $+0.75 \mathrm{~V}$, with sensitivity ranging from 5 to $50 \mathrm{nA}$. At a flow rate of $0.8 \mathrm{ml} / \mathrm{min}$, the separation procedure was carried out. $20 \mu \mathrm{l}$ of samples were manually injected. On the day of the experiment, brain samples were homogenized in $0.2 \mathrm{~mol} / \mathrm{L}$ perchloric acid. The samples were then centrifuged for 5 minutes at 12,000 Loading [MathJax]/jax/output/CommonHTML/jax.js im nylon filters before being injected into the HPLC sample 
injector. With the help of the breeze program, data were collected and evaluated. Using a standard with a concentration of $10-100 \mathrm{mg} / \mathrm{ml}$, serotonin concentrations were determined from the standard curve (Sharma et al., 2021).

\section{Assessment of brain dopamine levels}

Dopamine levels in striatal tissue samples were measured using Tiwari and colleague's technique. Dopamine activity in rat brain homogenate quantified as $\mathrm{ng} / \mathrm{mg}$ protein (Tiwari et al., 2021).

Assessment of brain glutamate levels

According to the Alam et al., glutamate was measured in tissue samples after derivatization with ophthalaldehyde/ $\beta$-mercaptoethanol (OPA/ $\beta$-ME) and quantitative analysis In rat brain homogenates, glutamate activity is reported as $\mathrm{ng} / \mathrm{mg}$ protein (Alam et al., 2020).

\section{Assessment of brain acetylcholine levels}

A diagnostic kit is used to measure acetylcholine (Krishgen diagnostics, India). All reagents and rat brain homogenate were produced according to the kit's normal procedure. In the microtiter plate, the optical density of the reaction mixture was determined at $540 \mathrm{~nm}$ (Mehan et al., 2020).

\section{Assessment of neuroinflammatory cytokines}

\section{Measurement of TNF- $a$ and IL-1 $\beta$ levels}

Using a rat immunoassay kit(KRISHGEN BioSystem, USA), the level of TNF-a was measured in rat brain homogenate (Mehan et al., 2018) and blood plasma. The activity of IL-1 $\beta$ was measured in rat brain homogenate and blood plasma as pg/mg protein (Tiwari et al., 2021).

\section{Estimation of oxidative stress markers}

Measurement of acetylcholinesterase (AChE) levels

The levels of acetylcholinesterase (AChE) were measured using spectrophotometry. The $0.05 \mathrm{ml}$ supernatant, $3 \mathrm{ml} 0.01 \mathrm{M}$ sodium phosphate buffer $(\mathrm{pH} 8), 0.10 \mathrm{ml}$ acetylthiocholine iodide, and $0.10 \mathrm{ml}$ DTNB were used in the test mixture (Ellman reagent). The absorbance change was spectrophotometrically recorded at $412 \mathrm{~nm}$ right away.In the supernatant, the enzymatic activity is represented as $\mu \mathrm{M} / \mathrm{mg}$ protein (Sharma et al., 2021).

\section{Measurement of reduced glutathione levels}

In the brain homogenate, the level of reduced glutathione was determined. $1 \mathrm{~mL}$ supernatant was precipitated with $1 \mathrm{~mL} 4 \%$ sulfosalicylic acid and cold digested for 1 hour at $4^{\circ} \mathrm{C}$. The samples were centrifuged for 15 minutes at $1200 \mathrm{rpm}$. To $1 \mathrm{ml}$ supernatant, $2.7 \mathrm{ml}$ phosphate buffer $(0.1 \mathrm{M}, \mathrm{pH} 8)$ and Loading [MathJax]/jax/output/CommonHTML/jax.js TNB) were added. A spectrophotometer was used to measure 
the yellow colour that emerged at $412 \mathrm{~nm}$ right away. Glutathione content in the supernatant, given as $\mu \mathrm{M} / \mathrm{mg}$ protein (Deshmukh et al., 2009).

\section{Measurement of nitrite levels}

A colorimetric assay utilizing Greiss reagent ( $0.1 \% \mathrm{~N}-(1$ - naphthyl) ethylenediamine dihydrochloride, \% sulfanilamide, and \% phosphoric acid) determines the concentration of nitrite in the supernatant, which is indicative of the formation of nitric oxide (NO). Equal amounts of supernatant and Greiss reagent are mixed, the mixture is incubated at room temperature in the dark for 10 minutes, and the absorbance is measured spectrophotometrically at $540 \mathrm{~nm}$. A sodium nitrite standard curve is used to calculate nitrite concentration in the supernatant, which is given as $\mu \mathrm{M} / \mathrm{mg}$ protein(Deshmukh et al., 2009).

\section{Measurement of malondialdehyde (MDA) levels}

The MDA end product of lipid peroxidation was determined quantitatively in brain homogenates. A spectrophotometer was used to measure the quantity of MDA after its reaction with thiobarbituric acid at $532 \mathrm{~nm}$. MDA concentration is expressed in $\mathrm{nM} / \mathrm{mg}$ of protein (Mehan et al., 2011).

Measurement of superoxide dismutase (SOD) levels

SOD activity was evaluated by auto-oxidation of epinephrine at $\mathrm{pH} 10.4$ using spectrophotometry. The brain homogenate supernatant $(0.2 \mathrm{ml})$ was combined with $0.8 \mathrm{ml}$ of $50 \mathrm{mM}$ glycine buffer, $\mathrm{pH} 10.4$, and the reaction was begun with $0.02 \mathrm{ml}$ epinephrine. The absorbance was spectrophotometrically measured at $480 \mathrm{~nm}$ after 5 minutes. The activity of SOD was measured in $\mathrm{nM} / \mathrm{mg}$ of protein (Sharma et al., 2019).

Measurement of lactate dehydrogenase (LDH) assay

A diagnostic kit (Coral Diagnostics, India) was used to quantify the amount of LDH in the rat brain homogenate, and the amount of LDH was quantified as Units/L. (Khera et al., 2019).

\section{Protein estimation}

A Coral protein estimation kit (Biuret method) was used to determine the protein content.

\section{Statistical analysis}

The mean and standard error of the mean was used to express all of the findings (SEM). The data were analyzed using a two-way ANOVA followed by a Bonferroni post hoc test and a one-way ANOVA followed by a Tukey's multi comparison test. It was determined that $P<0.001$ was statistically significant. The sample size was estimated after the data was confirmed to be normalized, and the normality distribution was checked using the Kolmogorov Smirnov test. GraphPad Prism version 5.03 for Windows was used to generate all statistical results (GraphPad Software, San Diego, CA, USA). The mean and standard error of the mean was used to express the statistical data (SEM). 


\subsection{Results}

\subsection{Neuroprotective potential of solanesol on weight variations in ouabain-induced bipolar disorder rats}

Improvement in body weight after solanesol treatment

Bodyweight was measured once a week, on days 1st, 7th, 14th, 21st, and 28th of the procedure schedule. Figure 2 depicts the differences in body weight caused by the toxin OUA compared to the treatment drugs over the protocol schedule. Compared to the vehicle, sham, and SNL80 perse treated groups, the administration of OUA for $1 \mathrm{st}$, 3rd, and 7th days resulted in a consistent decline in body weight. From day 8th to day 28th, rats receiving prolonged oral treatment with SNL and Lithium demonstrate a remarkable restoration in body weight due to improvements in psychiatric behaviors such as decreased locomotor activity, rearing, stress, and increased food intake.

Compared to SNL40 and SNL80 mg/kg treated rats, the Li60 mg/kg treated rats showed a more significant improvement in body weight. In addition, compared to other drug treatment groups such as SNL40 mg/kg, SNL80 mg/kg, and Li60 mg/ $\mathrm{kg}$; standard drug Li60 mg/kg in combination with SNL80 $\mathrm{mg} / \mathrm{kg}$ showed significant weight restoration. SNL $80 \mathrm{mg} / \mathrm{kg}$ has been shown to be more effective than SNL40 mg/kg in recovering OUA-induced lower body weight, demonstrating that SNL has a dosedependent impact on restoring body weight [Two-way ANOVA: $F(28,160)=903.4, p<0.001]$. (Fig. 2 )

\subsection{Neuroprotective potential of solanesol in the prevention of neurobehavioral abnormalities in ouabain-induced bipolar disorder rats}

Decrease manic-like behavior after solanesol treatment in the open field task

Three days ( $1 \mathrm{st}, 3 \mathrm{rd}$, and 7 th ) following a single OUA injection, the animals developed manic-like behaviors, as seen by the increased number of crossings, rearings, and time spent in the centre. Open field parameters were conducted on days $1 \mathrm{st}, 7 \mathrm{th}, 14 \mathrm{th}, 21 \mathrm{st}$, and $28 \mathrm{th}$ of the protocol period to determine the number of crossings, number of rearings, and time spent in the centre in rats.

\section{Decrease number of crossing after solanesol treatment}

The number of boxes crossed by rats in an open field is depicted in Fig. 3a. There was no significant difference between the groups on the 1st day. The OUA-treated rats crossed more boxes than the vehicle, sham, and SNL80-treated rats. On the 7th day, there was no significant difference between the OUAtreated group and the other treatment groups. After 20 days of oral administration of the neurotoxic OUA, the SNL treatment group had a progressive reduction in the number of boxes crossing compared to the normal control, vehicle control, and SNL80 perse groups on days 14th, 21st, and 28th. At the 21 st and Loading [MathJax]/jax/output/CommonHTML/jax.js 
considerably reduced the number of boxes crossing than the SNL80 mg/ $\mathrm{kg}$ and SNL40 mg/kg treated groups. Furthermore, when comparing SNL80 mg/kg treatment to SNL40 mg/kg treatment in BD rats, animals showed a lesser number of boxes crossed [Two-way ANOVA: $F(28,160)=190.0, p<0.001$ ].

(Fig. 3a)

\section{Decrease number of rearing after solanesol treatment}

In the open field, the number of rearing behaviors in BD rats is shown in Fig. 3b. On the 1st day, there was no significant difference between the groups. The OUA-treated rats showed more rearing moves than the vehicle control, sham control, and SNL80 treated rats. There was no significant difference between the OUA treated and other treatment groups on the 7th day. On days 14th, 21 st, and 28th, after 20 days of oral administration of the OUA, the number of rearings in the SNL treated groups decreased over time compared to the normal control, vehicle control, and SNL80 perse groups. The Li60 mg/kg alone and Li60 $\mathrm{mg} / \mathrm{kg}$ along with SNL80 mg/kg treated animals showed a significantly lesser number of rearing on $21 \mathrm{st}$ and 28 th days than the SNL80 mg/kg and SNL40 mg/kg treated groups. Furthermore, when BD rats were given SNL80 $\mathrm{mg} / \mathrm{kg}$ versus SNL40 $\mathrm{mg} / \mathrm{kg}$, the animals showed a lesser number of rearing movements. [Two-way ANOVA: $F(28,160)=39.51, p<0.001]$. (Fig. 3b)

\section{Decrease time spent in the centre after solanesol treatment}

Figure $3 c$ indicates BD rats in the open field time spent in the centre. On the 1st day, there was no significant difference between the groups. The OUA-treated rats stayed longer than vehicle, sham, and SNL80-treated rats. There was no significant difference between the OUA-treated group and the other treatment groups on the seventh day. On days 14th, 21st, and 28th compared to the normal control, vehicle control, and SNL80 perse groups, time spent in the centre in the SNL treated groups reduced over time following 20days of oral administration of the OUA.The Li60 mg/kg alone and Li60 mg/kg combined with SNL80 $\mathrm{mg} / \mathrm{kg}$ treated animals spent significantly less time in the centre on the $21 \mathrm{st}$ and 28th days than the SNL80 mg/kg and SNL40 mg/kg treated groups. Moreover, BD rats administered SNL80 mg/kg spent less time in the centre than rats given SNL40 mg/kg. [Two-wayANOVA: $F(28,160)=$ 27.00, p < 0.001]. (Fig. 3c)

\section{Decreased manic-like behavior after solanesol treatment}

As illustrated in Fig. 4, the results suggest that OUA significantly affects locomotor activity in BD rats. On the 1st day, there was no significant difference between the groups. Rats were given OUA on days 1st, 3rd, and 7th, demonstrating considerably higher locomotor activity during the protocol schedule compared to the vehicle control, sham control, and SNL80 treated rats. Locomotor activity decreased from day 8th to day 28th after SNL treatment, as observed with the mood stabilizer Li60 mg/kg treated rats. Compared to the SNL80 $\mathrm{mg} / \mathrm{kg}$ and SNL40 mg/kg treatment groups, Li60 mg/kg administration, both alone and in combination with SNL80 mg/kg, significantly reduced locomotor activity. In addition, SNL80 mg/kg significantly reduced locomotor activity in actophotometer rats when compared to SNL40 mg/kg treated 
SNL have an antimanic effect when given alone and a more significant enhancement in antimanic action when given together during OUA-induced BD rats on days 18th and 27th. (Fig. 4)

Decreased depression-like behavior after solanesol treatment

As shown in Fig. 5, the results reveal that OUA has a considerable influence on immobility time in BD rats. On the 1st day, there was no significant difference between the groups. Rats were given OUA on days 1st, 3rd, and 7th had significantly prolonged immobility time during the protocol schedule compared to the vehicle control, sham control, and SNL80 perse treated rats. From day 8th to day 28th, immobility time was significantly reduced with SNL treatment, as reported with the mood stabilizer Li60 mg/kg. Li60 $\mathrm{mg} / \mathrm{kg}$ treatment, both alone and in combination with SNL80 $\mathrm{mg} / \mathrm{kg}$, significantly reduced immobility time compared to the SNL80 mg/kg and SNL40 mg/kg treatment groups. Furthermore, compared to $\mathrm{SNL} 40 \mathrm{mg} / \mathrm{kg}$ treated rats on day $27 \mathrm{th}, \mathrm{SNL} 80 \mathrm{mg} / \mathrm{kg}$ significantly reduced immobility time in FST rats [Two-way ANOVA: $F(21,120)=244.1, p<0.001]$. Li60 mg/kg and SNL80 mg/kg showed an antidepressant effect when administered alone on day 27th in OUA-induced BD rats and a more significant effect when given in combination (Fig. 5)

\subsection{Neuroprotective potential of solanesol on neurochemical alterations in ouabain-induced bipolar disorder rats}

Increased SIRT-1 level after long-term administration of solanesol

At the end of the protocol schedule, SIRT-1 levels were measured in rat brain homogenate, blood plasma, and CSF samples. Compared to normal control, vehicle control, and SNL80 perse groups, the ICV injection of OUA resulted in a significant decline in SIRT-1 levels. The level of SIRT-1 in brain homogenate [One-way ANOVA: $F(7,35)=4.472, P<0.001$ ], blood plasma [One-way ANOVA: $F(7,35)=5.938, P<0.001$ ], and CSF [One-way ANOVA: $F(7,35)=1.243, P<0.001$ ] samples were elevated after continuous oral administration of SNL at doses of $40 \mathrm{mg} / \mathrm{kg}$ and $80 \mathrm{mg} / \mathrm{kg}$. In rat brain homogenate, blood plasma, and CSF samples, SNL80 mg/ $\mathrm{kg}$ was more effective than SNL $40 \mathrm{mg} / \mathrm{kg}$ in restoring SIRT-1 protein expression. Furthermore, the Li60 mg/kg alone and Li60 mg/kg in combination with SNL80 mg/kg treated groups were more effective in restoring SIRT-1 protein expression in rat brain homogenate, blood plasma, and CSF samples than the SNL80 $\mathrm{mg} / \mathrm{kg}$ and SNL40 $\mathrm{mg} / \mathrm{kg}$ treated groups. (Table 1) 
Table 1

Neuroprotective potential of solanesol on SIRT-1 level in ouabain-induced bipolar disorder in rats

\begin{tabular}{|c|c|c|c|c|}
\hline \multirow[t]{2}{*}{ S.no. } & \multirow[t]{2}{*}{ Groups } & \multicolumn{3}{|l|}{ SIRT-1 } \\
\hline & & 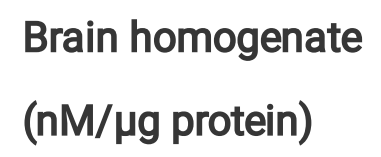 & $\begin{array}{l}\text { Blood plasma } \\
(\mathrm{ng} / \mathrm{ml})\end{array}$ & $\begin{array}{l}\text { CSF } \\
(\mathrm{ng} / \mathrm{ml})\end{array}$ \\
\hline 1. & Vehicle control & $311.20 \pm 5.164$ & $6.07 \pm 0.074$ & $3.29 \pm 0.073$ \\
\hline 2. & Sham control & $312.30 \pm 5.102$ & $6.07 \pm 0.105$ & $3.33 \pm 0.047$ \\
\hline 3. & SNL80 perse & $311.90 \pm 4.278$ & $6.00 \pm 0.081$ & $3.26 \pm 0.052$ \\
\hline 4. & OUA & $153.20 \pm 9.224 *$ & $2.43 \pm 0.100 *$ & $0.80 \pm 0.065^{*}$ \\
\hline 5. & OUA + SNL40 & $180.50 \pm 2.832^{\#}$ & $3.28 \pm 0.071^{\#}$ & $1.35 \pm 0.048^{\#}$ \\
\hline 6. & OUA + SNL80 & $210.50 \pm 3.103^{\# \$}$ & $3.79 \pm 0.074^{\# \$}$ & $1.64 \pm 0.045^{\# \$}$ \\
\hline 7. & OUA + Li60 & $237.60 \pm 3.616^{\# \beta}$ & $4.29 \pm 0.066^{\# \beta}$ & $1.92 \pm 0.041_{\# \beta}$ \\
\hline 8. & OUA + SNL80 + Li60 & $267.40 \pm 2.215^{\# @ ~}$ & $4.77 \pm 0.077 \# @$ & $2.25 \pm 0.036 \# @$ \\
\hline
\end{tabular}

Decreased level of caspase-3, Bax, and increased Bcl-2 levels after long-term administration of solanesol

The levels of cell death indicators such as Caspase-3, Bax, and Bcl-2 were measured in rat brain homogenate and blood plasma samples after the protocol schedule. In rat brain homogenate and blood plasma samples, ICV injection of OUA treatment resulted in a significant increase in pro-apoptotic markers such as caspase-3 and Bax. In contrast, the ICV injection of OUA for three days (1st, 3rd, and 7th) resulted in a significant decrease in anti-apoptotic Bcl-2 protein levels in rat brain homogenate and blood plasma samples compared to the normal control, vehicle control, and SNL80 perse treated groups.

Chronic oral treatment of SNL40 mg/kg and SNL80 mg/kg significantly lowered caspase-3 levels in brain homogenate [One-way ANOVA: $\mathrm{F}(7,35)=0.522, \mathrm{P}<0.001$ ] and blood plasma samples [One-way ANOVA: $F(7,35)=1.739, P<0.001]$ respectively

Similarly, continuous oral administration of SNL40 mg/kg and $80 \mathrm{mg} / \mathrm{kg}$ significantly reduced the amount of pro-apoptotic Bax in rat brain homogenate [One-way ANOVA: $F(7,35)=1.092, P<0.001$ ] and blood plasma samples [One-way ANOVA: $F(7,35)=1.628, \mathrm{P}<0.001$ ].

Furthermore, regular oral administration of SNL at doses of $40 \mathrm{mg} / \mathrm{kg}$ and $80 \mathrm{mg} / \mathrm{kg}$ for 20 days (day 8th to 28th ) resulted in a significant rise in Bcl-2 protein levels in brain homogenate [One-way ANOVA: $F(7$,

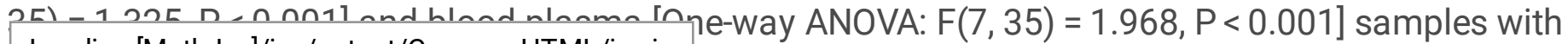
Loading [MathJax]/jax/output/CommonHTML/jax.js 
respect to the OUA-treated BD rats. Also, SNL80 mg/kg treatment was more effective than SNL40 mg/kg treatment in restoring abnormal levels of apoptotic markers in BD rats. Furthermore, in rat brain homogenate and blood plasma, the Li60 mg/kg alone and Li60 mg/kg combined with SNL80 mg/kg treated groups showed more significance in restoring the altered levels of apoptotic markers than the $\mathrm{SNL} 80 \mathrm{mg} / \mathrm{kg}$ and SNL40 $\mathrm{mg} / \mathrm{kg}$ treated groups. (Table 2)

Table 2

Neuroprotective potential of solanesol on Caspase-3, Bax, and Bcl-2 level in ouabain-induced bipolar disorder in rats

\begin{tabular}{|c|c|c|c|c|c|c|c|}
\hline \multirow{4}{*}{$\begin{array}{l}\text { S. } \\
\text { no. }\end{array}$} & \multirow[t]{4}{*}{ Groups } & \multicolumn{6}{|c|}{ Apoptotic markers } \\
\hline & & \multicolumn{2}{|l|}{ Caspase-3 } & \multicolumn{2}{|l|}{ Bax } & \multicolumn{2}{|l|}{$\mathrm{Bcl}-2$} \\
\hline & & $\begin{array}{l}\text { Brain } \\
\text { homogenate }\end{array}$ & $\begin{array}{l}\text { Blood } \\
\text { plasma }\end{array}$ & $\begin{array}{l}\text { Brain } \\
\text { homogenate }\end{array}$ & $\begin{array}{l}\text { Blood } \\
\text { plasma }\end{array}$ & $\begin{array}{l}\text { Brain } \\
\text { homogenate }\end{array}$ & $\begin{array}{l}\text { Blood } \\
\text { plasma }\end{array}$ \\
\hline & & $\begin{array}{l}\text { (nM/mg } \\
\text { protein) }\end{array}$ & (ng/ml) & $\begin{array}{l}\text { (ng/mg } \\
\text { protein) }\end{array}$ & $(\mathrm{ng} / \mathrm{ml})$ & $\begin{array}{l}\text { (ng/mg } \\
\text { protein) }\end{array}$ & (ng/ml) \\
\hline 1. & $\begin{array}{l}\text { Vehicle } \\
\text { control }\end{array}$ & $\begin{array}{l}89.96 \pm \\
0.861\end{array}$ & $\begin{array}{l}1.71 \pm \\
0.028\end{array}$ & $6.60 \pm 0.190$ & $\begin{array}{l}0.90 \pm \\
0.061\end{array}$ & $\begin{array}{l}26.77 \pm \\
0.133\end{array}$ & $\begin{array}{l}6.44 \pm \\
0.049\end{array}$ \\
\hline 2. & $\begin{array}{l}\text { Sham } \\
\text { control }\end{array}$ & $\begin{array}{l}90.07 \pm \\
0.819\end{array}$ & $\begin{array}{l}1.68 \pm \\
0.020\end{array}$ & $6.73 \pm 0.126$ & $\begin{array}{l}0.90 \pm \\
0.058\end{array}$ & $\begin{array}{l}26.65 \pm \\
0.144\end{array}$ & $\begin{array}{l}6.51 \pm \\
0.070\end{array}$ \\
\hline 3. & $\begin{array}{l}\text { SNL80 } \\
\text { perse }\end{array}$ & $\begin{array}{l}90.18 \pm \\
0.947\end{array}$ & $\begin{array}{l}1.69 \pm \\
0.029\end{array}$ & $6.62 \pm 0.125$ & $\begin{array}{l}0.86 \pm \\
0.061\end{array}$ & $\begin{array}{l}26.57 \pm \\
0.177\end{array}$ & $\begin{array}{l}6.49 \pm \\
0.044\end{array}$ \\
\hline 4. & OUA & $\begin{array}{l}132.10 \pm \\
0.717^{*}\end{array}$ & $\begin{array}{l}4.79 \pm \\
0.073^{\star}\end{array}$ & $\begin{array}{l}11.76 \pm \\
0.089^{*}\end{array}$ & $\begin{array}{l}4.58 \pm \\
0.062^{\star}\end{array}$ & $\begin{array}{l}18.80 \pm \\
0.117^{\star}\end{array}$ & $\begin{array}{l}1.70 \pm \\
0.072^{\star}\end{array}$ \\
\hline 5. & $\begin{array}{l}\text { OUA+ } \\
\text { SNL40 }\end{array}$ & $\begin{array}{l}117.90 \pm \\
0.677^{\#}\end{array}$ & $\begin{array}{l}3.71 \pm \\
0.075^{\#}\end{array}$ & $\begin{array}{l}10.67 \pm \\
0.074^{\#}\end{array}$ & $\begin{array}{l}4.07 \pm \\
0.061^{\#}\end{array}$ & $\begin{array}{l}21.54 \pm \\
0.147^{\#}\end{array}$ & $\begin{array}{l}2.79 \pm \\
0.063^{\#}\end{array}$ \\
\hline 6. & $\begin{array}{l}\text { OUA+ } \\
\text { SNL80 }\end{array}$ & $\begin{array}{l}112.80 \pm \\
0.779^{\# \$}\end{array}$ & $\begin{array}{l}3.29 \pm \\
0.067 \# \$\end{array}$ & $\begin{array}{l}9.79 \pm \\
0.074^{\# \$}\end{array}$ & $\begin{array}{l}3.52 \pm \\
0.061^{\# \$}\end{array}$ & $\begin{array}{l}22.81 \pm \\
0.106^{\# \$}\end{array}$ & $\begin{array}{l}3.62 \pm \\
0.077^{\# \$}\end{array}$ \\
\hline 7. & OUA + Li60 & $\begin{array}{l}108.10 \pm \\
0.812^{\# \beta}\end{array}$ & $\begin{array}{l}2.78 \pm \\
0.069^{\# \beta}\end{array}$ & $\begin{array}{l}8.70 \pm \\
0.068^{\# \beta}\end{array}$ & $\begin{array}{l}2.38 \pm \\
0.061^{\# \beta}\end{array}$ & $\begin{array}{l}23.79 \pm \\
0.118^{\# \beta}\end{array}$ & $\begin{array}{l}4.57 \pm \\
0.077^{\# \beta}\end{array}$ \\
\hline 8. & $\begin{array}{l}\text { OUA + } \\
\text { SNL80 + } \\
\text { Li60 }\end{array}$ & $\begin{array}{l}102.40 \pm \\
0.793^{\# @}\end{array}$ & $\begin{array}{l}2.29 \pm \\
0.064^{\# @}\end{array}$ & $\begin{array}{l}7.78 \pm \\
0.074^{\# @}\end{array}$ & $\begin{array}{l}1.61 \pm \\
0.040^{\# @}\end{array}$ & $\begin{array}{l}24.83 \pm \\
0.106^{\# @}\end{array}$ & $\begin{array}{l}5.32 \pm \\
0.045^{\# @}\end{array}$ \\
\hline $\begin{array}{l}\text { Stat } \\
\text { SEN } \\
\text { V/S } \\
\text { Li60 }\end{array}$ & $\begin{array}{l}\text { sal analys } \\
=6 \text { rats } p \\
; \# \$ p<0\end{array}$ & $\begin{array}{l}\text { llowed by o } \\
\text { Jup). * } p<0 \\
\text { v/s OUA + }\end{array}$ & $\begin{array}{l}\text { ay AN } \\
\text { v/s v } \\
0 ; \# \beta\end{array}$ & $\begin{array}{l}\text { ost-hoc Tu } \\
\text { control, sha } \\
1 \mathrm{v} / \mathrm{s} \text { OUA }\end{array}$ & $\begin{array}{l}\text { test). } \\
\text { ntrol } \\
\text { IL40 }\end{array}$ & $\begin{array}{l}\text { s expressed } \\
\text { NL80 perse; } \\
\text { JA + SNL80; }\end{array}$ & $\begin{array}{l}\text { mean } \pm \\
<0.001 \\
\text { OUA }+\end{array}$ \\
\hline
\end{tabular}

Restoration of mitochondrial ETC-complexes enzyme level after long-term administration of solanesol

After the experiment protocol schedule, the enzyme activity of mitochondrial ETC-complexes was Loading [MathJax]/jax/output/CommonHTML/jax.js ys intoxications of OUA in rats through ICV injection resulted 
in a significant decrease in mitochondrial ETC complexes-I [One-way ANOVA: $F(7,35)=1.796, P<0.001]$, complexes-II [One-way ANOVA: $F(7,35)=2.936, P<0.001$, complexes-IV [One-way ANOVA: $F(7,35)=$ $6.744, \mathrm{P}<0.001$ ], and complexes-V [One-way ANOVA: $F(7,35)=0.979, \mathrm{P}<0.001]$ and CoQ10 level [Oneway ANOVA: $F(7,35)=4.381, P<0.001]$, when compared to the vehicle, sham control, and SNL80 perse groups.

In OUA-treated rats, twenty days of chronic administration with SNL40mg/kg and SNL80 mg/kg substantially and dose-dependently recovers and increases mitochondrial ETC complex enzymatic activity. The significant restoration was observed with a high dose of SNL80 mg/kg group in mitochondrial ETC complexes-I, II, IV, V, and CoQ10 compared to a low dose of SNL40 mg/kg. The most significant improvements in mitochondrial ETC complexes-I, II, IV, V, and CoQ10 in rat brain homogenate were seen in the Li60 mg/kg alone and Li60 mg/kg in combination with SNL80 mg/kg treated groups, which were more effective than the SNL80 mg/kg and SNL40 mg/kg treated groups. (Table 3) 
Table 3

Neuroprotective potential of solanesol on TNF- $\alpha$ and IL-1 $\beta$ level in ouabain-induced bipolar disorder in rats

\begin{tabular}{|c|c|c|c|c|c|}
\hline \multirow{5}{*}{$\begin{array}{l}\text { S. } \\
\text { no. }\end{array}$} & \multirow[t]{5}{*}{ Groups } & \multicolumn{4}{|c|}{ Neuroinflammatory markers } \\
\hline & & \multirow{2}{*}{\multicolumn{2}{|c|}{$\begin{array}{l}\text { TNF-a } \\
\text { (pg/mg protein) }\end{array}$}} & \multirow{2}{*}{\multicolumn{2}{|c|}{$\begin{array}{l}\text { IL-1 } \beta \\
\text { (pg/mg protein) }\end{array}$}} \\
\hline & & & & & \\
\hline & & $\begin{array}{l}\text { Brain } \\
\text { homogenate }\end{array}$ & Blood plasma & $\begin{array}{l}\text { Brain } \\
\text { homogenate }\end{array}$ & Blood plasma \\
\hline & & \multicolumn{2}{|l|}{$\begin{array}{l}\text { (nM/mg } \\
\text { protein) }\end{array}$} & \multicolumn{2}{|l|}{ (ng/mg protein) } \\
\hline 1. & Vehicle control & $28.16 \pm 0.594$ & $20.67 \pm 0.330$ & $14.52 \pm 0.143$ & $14.39 \pm 0.248$ \\
\hline 2. & Sham control & $28.18 \pm 0.535$ & $20.94 \pm 0.314$ & $14.47 \pm 0.126$ & $14.15 \pm 0.219$ \\
\hline 3. & SNL80 perse & $28.53 \pm 0.542$ & $20.97 \pm 0.324$ & $14.49 \pm 0.113$ & $14.50 \pm 0.240$ \\
\hline 4. & OUA & $61.02 \pm 0.827 *$ & $\begin{array}{l}96.21 \pm \\
1.371^{\star}\end{array}$ & $26.15 \pm 0.151^{\star}$ & $77.49 \pm 0.560^{*}$ \\
\hline 5. & OUA + SNL40 & $53.15 \pm 0.778^{\#}$ & $\begin{array}{l}72.76 \pm \\
1.096^{\#}\end{array}$ & $22.61 \pm 0.055^{\#}$ & $57.12 \pm 0.608^{\#}$ \\
\hline 6. & OUA + SNL80 & $46.80 \pm 0.723^{\# \$}$ & $\begin{array}{l}57.51 \pm \\
0.648^{\# \$}\end{array}$ & $21.79 \pm 0.067^{\# \$}$ & $\begin{array}{l}42.34 \pm \\
0.609^{\# \$}\end{array}$ \\
\hline 7. & $O U A+L i 60$ & $40.86 \pm 0.745^{\# \beta}$ & $\begin{array}{l}43.84 \pm \\
0.502^{\# \beta}\end{array}$ & $20.70 \pm 0.068^{\# \beta}$ & $\begin{array}{l}26.74 \pm \\
0.454^{\# \beta}\end{array}$ \\
\hline 8. & $\begin{array}{l}\text { OUA + SNL80 + } \\
\text { Li60 }\end{array}$ & $35.77 \pm 0.745^{\# @ ~}$ & $\begin{array}{l}27.70 \pm \\
0.502^{\# @}\end{array}$ & $19.67 \pm 0.051^{\# @}$ & $\begin{array}{l}19.30 \pm \\
0.313^{\# @}\end{array}$ \\
\hline \multicolumn{6}{|c|}{$\begin{array}{l}\text { Statistical analysis followed by one-way ANOVA (post-hoc Tukey's test). Values expressed as mean } \pm \\
\text { SEM }(n=6 \text { rats per group). * } p<0.001 \mathrm{v} / \mathrm{s} \text { vehicle control, sham control and SNL80 perse; } \# p<0.001 \\
\text { V/s OUA; } \# \$ p<0.001 \mathrm{v} / \mathrm{s} \text { OUA }+ \text { SNL40; } \# \beta p<0.001 \mathrm{v} / \mathrm{s} \text { OUA }+ \text { SNL40 and OUA + SNL80; \#@ OUA + } \\
\text { Li60 }\end{array}$} \\
\hline
\end{tabular}

Restoration of neurotransmitter level after long-term administration of solanesol

Neurochemicals such as serotonin, dopamine, glutamate, and acetylcholine were analysed in rat brain homogenate samples at the end of the experimental protocol schedule. The injection of OUA through the ICV route considerably reduced serotonin and acetylcholine levels.ICV injection of OUA intoxication resulted in a significant increase in dopamine and glutamate concentrations in brain homogenate compared to normal control, vehicle control, and SNL80 perse treated rats. Treatment with SNL40 mg/kg and $80 \mathrm{mg} / \mathrm{kg}$ significantly and dose-dependently increased serotonin [One-way ANOVA: $F(7,35)=4.031$, $P<0.001$ ] as well as acetylcholine level [One-way ANOVA: $F(7,35)=3.607, P<0.001$ ]. In contrast to the OUA-treated BD rats. prolonaed oral administration of SNL40 mg/ $\mathrm{kg}$ and SNL80 mg/ $\mathrm{kg}$ decreased the Loading [MathJax]/jax/output/CommonHTML/jax.js 
concentrations of dopamine [One-way ANOVA: $F(7,35)=1.000, P<0.001$ ] and glutamate [One-way ANOVA: $F(7,35)=1.963, P<0.001]$ in rat brain homogenate. Moreover, SNL80 mg $/ \mathrm{kg}$ versus SNL40 $\mathrm{mg} / \mathrm{kg}$ treated rats re-establish lower neurotransmitter levels. The Li60 mg/kg alone and Li60 mg/kg combined with SNL80 mg/kg treated groups were more effective than the SNL80 mg/kg and SNL40 $\mathrm{mg} / \mathrm{kg}$ treated groups in restoring the altered levels of neurotransmitters in rat brain homogenate.

(Table 4)

Table 4

Neuroprotective potential of solanesol on neurotransmitters level in ouabain-induced bipolar disorder in rats

\begin{tabular}{|c|c|c|c|c|c|}
\hline \multirow{2}{*}{$\begin{array}{l}\text { S. } \\
\text { no. }\end{array}$} & \multirow[t]{2}{*}{ Groups } & \multicolumn{4}{|c|}{ Neurotransmitters } \\
\hline & & $\begin{array}{l}\text { Serotonin } \\
\text { (ng/mg } \\
\text { protein) }\end{array}$ & $\begin{array}{l}\text { Acetylcholine } \\
\text { (ng/mg } \\
\text { protein) }\end{array}$ & $\begin{array}{l}\text { Glutamate } \\
\text { (ng/mg protein) }\end{array}$ & $\begin{array}{l}\text { Dopamine } \\
\text { (ng/mg } \\
\text { protein) }\end{array}$ \\
\hline 1. & Vehicle control & $35.69 \pm 0.413$ & $6.63 \pm 0.121$ & $92.13 \pm 1.413$ & $77.13 \pm 1.332$ \\
\hline 2. & Sham control & $35.64 \pm 0.516$ & $6.54 \pm 0.120$ & $92.15 \pm 1.305$ & $77.21 \pm 1.215$ \\
\hline 3. & SNL80 perse & $35.59 \pm 0.444$ & $6.62 \pm 0.147$ & $92.05 \pm 1.492$ & $78.10 \pm 1.228$ \\
\hline 4. & OUA & $13.46 \pm 0.527^{\star}$ & $0.52 \pm 0.114^{\star}$ & $240.60 \pm 1.808^{\star}$ & $63.49 \pm 0.967^{*}$ \\
\hline 5. & OUA + SNL40 & $17.69 \pm 0.430^{\#}$ & $1.78 \pm 0.079^{\#}$ & $195.30 \pm 1.502^{\#}$ & $55.16 \pm 0.640 \#$ \\
\hline 6. & OUA + SNL80 & $\begin{array}{l}21.92 \pm \\
0.446^{\# \$}\end{array}$ & $2.83 \pm 0.084^{\# \$}$ & $\begin{array}{l}165.30 \pm \\
1.412^{\# \$}\end{array}$ & $\begin{array}{l}45.61 \pm \\
0.566^{\# \$}\end{array}$ \\
\hline 7. & OUA + Li60 & $\begin{array}{l}25.66 \pm \\
0.452^{\# \beta}\end{array}$ & $3.78 \pm 0.077^{\# \beta}$ & $\begin{array}{l}136.40 \pm \\
1.473^{\# \beta}\end{array}$ & $\begin{array}{l}37.83 \pm \\
0.765^{\# \beta}\end{array}$ \\
\hline 8. & $\begin{array}{l}\text { OUA + SNL80 + } \\
\text { Li60 }\end{array}$ & $\begin{array}{l}30.01 \pm \\
0.446^{\# @}\end{array}$ & $4.78 \pm 0.077^{\# @ ~}$ & $\begin{array}{l}116.30 \pm \\
1.487^{\# @}\end{array}$ & $\begin{array}{l}27.22 \pm \\
1.897^{\# @}\end{array}$ \\
\hline \multicolumn{6}{|c|}{$\begin{array}{l}\text { Statistical analysis followed by one-way ANOVA (post-hoc Tukey's test). Values expressed as mean } \pm \\
\text { SEM }(n=6 \text { rats per group). * } p<0.001 \mathrm{v} / \mathrm{s} \text { vehicle control, sham control and SNL80 perse; } \#<<0.001 \\
\text { v/s OUA; \#\$ } p<0.001 \mathrm{v} / \mathrm{s} \text { OUA + SNL40; \# } \beta p<0.001 \mathrm{v} / \mathrm{s} \text { OUA + SNL40 and OUA + SNL80; \#@ OUA + } \\
\text { Li60 }\end{array}$} \\
\hline
\end{tabular}

Reduction in neuroinflammatory cytokines after long-term administration of solanesol

We measured the levels of pro-inflammatory cytokines like TNF- $\alpha$ and IL-1 $\beta$ in the whole brain homogenate and blood plasma samples of rats to see whether SNL had a therapeutic effect in OUAinduced BD rats. SNL therapy at doses of $40 \mathrm{mg} / \mathrm{kg}$ and $80 \mathrm{mg} / \mathrm{kg}$ reduced TNF-aexpression in rat brain homogenate [One-way ANOVA: $F(7,35)=1.065, \mathrm{P}<0.001$ ] and blood plasma samples [One-way ANOVA: $F(7,35)=0.589, P<0.001]$. Similarly, chronic oral treatment with SNL40 mg/kg and SNL80 mg/kg remarkably decreased the level of IL-1 $\beta$ in brain homogenate [One-way ANOVA: $F(7,35)=0.348, P<0.001$ ] Loading [MathJax]/jax/output/CommonHTML/jax.js 
and blood plasma samples [One-way ANOVA: $F(7,35)=0.691, P<0.001$ ], as opposed to the OUA toxin administered BD rats. Meanwhile, compared to the SNL40 mg/kg dose, SNL80 mg/ $\mathrm{kg}$ demonstrated a significant improvement in lowering the expression of these inflammatory mediators. In rat brain homogenate and blood plasma samples, the Li60 mg/kg alone and Li60 mg/kg in conjunction with SNL80 $\mathrm{mg} / \mathrm{kg}$ treated groups exhibited a substantial improvement in lowering the level of these inflammatory mediators compared to the SNL80 mg/kg and SNL40 mg/kg treated groups at the end of protocol schedule. (Table 5)

Table 5

Neuroprotective potential of solanesol in restoration of mitochondrial ETC complex enzymes in ouabaininduced bipolar disorder in rats

\begin{tabular}{|c|c|c|c|c|c|c|}
\hline \multirow{3}{*}{$\begin{array}{l}\text { S. } \\
\text { no. }\end{array}$} & \multirow[t]{3}{*}{ Groups } & \multicolumn{5}{|c|}{ Mitochondrial complexes estimation } \\
\hline & & Complex-I & Complex-II & Complex-IV & Complex-V & CoQ10 \\
\hline & & $\begin{array}{l}\text { (nM/mg } \\
\text { protein) }\end{array}$ & $\begin{array}{l}\text { (nM/mg } \\
\text { protein) }\end{array}$ & $\begin{array}{l}\text { (nM/mg } \\
\text { protein) }\end{array}$ & $\begin{array}{l}\text { (nM/mg } \\
\text { protein) }\end{array}$ & $\begin{array}{l}\text { (nM/mg } \\
\text { protein) }\end{array}$ \\
\hline 1. & Vehicle control & $9.71 \pm 0.077$ & $\begin{array}{l}11.77 \pm \\
0.088\end{array}$ & $\begin{array}{l}211.10 \pm \\
1.505\end{array}$ & $\begin{array}{l}450.40 \pm \\
3.675\end{array}$ & $9.28 \pm 0.240$ \\
\hline 2. & Sham control & $9.73 \pm 0.063$ & $\begin{array}{l}11.83 \pm \\
0.089\end{array}$ & $\begin{array}{l}210.70 \pm \\
1.173\end{array}$ & $\begin{array}{l}451.20 \pm \\
2.648\end{array}$ & $9.08 \pm 0.263$ \\
\hline 3. & SNL80 perse & $9.77 \pm 0.082$ & $\begin{array}{l}11.85 \pm \\
0.083\end{array}$ & $\begin{array}{l}209.80 \pm \\
1.573\end{array}$ & $\begin{array}{l}449.20 \pm \\
3.251\end{array}$ & $9.00 \pm 0.305$ \\
\hline 4. & OUA & $\begin{array}{l}4.33 \pm \\
0.053^{\star}\end{array}$ & $\begin{array}{l}3.52 \pm \\
0.141^{\star}\end{array}$ & $\begin{array}{l}118.00 \pm \\
0.740^{\star}\end{array}$ & $\begin{array}{l}160.60 \pm \\
3.673^{*}\end{array}$ & $\begin{array}{l}2.03 \pm \\
0.051 *\end{array}$ \\
\hline 5. & OUA + SNL40 & $\begin{array}{l}5.74 \pm \\
0.078^{\#}\end{array}$ & $\begin{array}{l}5.28 \pm \\
0.071^{\#}\end{array}$ & $\begin{array}{l}130.30 \pm \\
1.366^{\#}\end{array}$ & $\begin{array}{l}210.20 \pm \\
2.504^{\#}\end{array}$ & $\begin{array}{l}3.28 \pm \\
0.084^{\#}\end{array}$ \\
\hline 6. & OUA + SNL80 & $\begin{array}{l}6.77 \pm \\
0.070^{\# \$}\end{array}$ & $\begin{array}{l}6.29 \pm \\
0.058^{\# \$}\end{array}$ & $\begin{array}{l}149.70 \pm \\
1.558^{\# \$}\end{array}$ & $\begin{array}{l}269.00 \pm \\
3.111^{\# \$}\end{array}$ & $\begin{array}{l}4.29 \pm \\
0.070^{\# \$}\end{array}$ \\
\hline 7. & OUA + Li60 & $\begin{array}{l}7.72 \pm \\
0.080^{\# \beta}\end{array}$ & $\begin{array}{l}7.33 \pm \\
0.052^{\# \beta}\end{array}$ & $\begin{array}{l}170.40 \pm \\
1.527^{\# \beta}\end{array}$ & $\begin{array}{l}342.20 \pm \\
3.014^{\# \beta}\end{array}$ & $\begin{array}{l}5.29 \pm \\
0.078 \# \beta\end{array}$ \\
\hline 8. & $\begin{array}{l}\text { OUA + SNL80 } \\
+ \text { Li } 60\end{array}$ & $\begin{array}{l}8.75 \pm \\
0.079 \# @\end{array}$ & $\begin{array}{l}8.20 \pm \\
0.074 \# @\end{array}$ & $\begin{array}{l}190.00 \pm \\
1.449 \# @\end{array}$ & $\begin{array}{l}391.00 \pm \\
3.117^{\# @}\end{array}$ & $\begin{array}{l}6.28 \pm \\
0.057 \# @\end{array}$ \\
\hline $\begin{array}{l}\text { St } \\
\text { SE } \\
\text { v/s } \\
\text { Lie }\end{array}$ & $\begin{array}{l}\text { cal analysis fo } \\
=6 \text { rats per grc } \\
; \# \$ p<0.001\end{array}$ & $\begin{array}{l}\text { d by one- } \\
* p<0.00 \\
\text { * } \mathrm{UA}+\mathrm{SNL}\end{array}$ & $\begin{array}{l}\text { ANOVA ( } \\
\text { a vehicle }\end{array}$ & $\begin{array}{l}\text { c Tukey's } \\
\text { sham col } \\
\text { OUA+SN }\end{array}$ & $\begin{array}{l}\text { /alues exp } \\
\text { nd SNL80 } \\
\text { d OUA + S }\end{array}$ & $\begin{array}{l}\text { d as mean } \pm \\
; \# p<0.001 \\
; \# @ \text { OUA + }\end{array}$ \\
\hline
\end{tabular}

Decreased oxidative stress markers and increased antioxidant levels after long-term administration of solanesol 
The levels of oxidative stress indicators such as AchE, LDH, MDA, nitrite, SOD, and GSH were measured in rat brain homogenate samples at the end of the experimental protocol schedule. The levels of AchE, LDH, MDA, and nitrite increased significantly after ICV injection of OUA. In contrast, antioxidant levels such as SOD and GSH decreased compared to the normal control, vehicle control, and SNL80 perse treated groups. Continuous oral treatment of SNL at doses of $40 \mathrm{mg} / \mathrm{kg}$ and $80 \mathrm{mg} / \mathrm{kg}$ for twenty days significantly lowered the levels of AchE [One-way ANOVA: $F(7,35)=2.867, \mathrm{P}<0.001$ ], LDH [One-way ANOVA: $F(7,35)=2.829, P<0.001]$, MDA [One-way ANOVA: $F(7,35)=3.681, P<0.001$ ] and nitrite [Oneway ANOVA: $F(7,35)=1.736, P<0.001]$.

However, SNL40 $\mathrm{mg} / \mathrm{kg}$ and SNL $80 \mathrm{mg} / \mathrm{kg}$ remarkably restored the anti-oxidant defense system by increasing the levels of GSH [One-way ANOVA: $F(7,35)=4.281, P<0.001$ ], and SOD [One-way ANOVA: $F(7$, $35)=6.111, P<0.001]$ when compared with OUA-treated BD rats. Furthermore, in comparison to SNL40 $\mathrm{mg} / \mathrm{kg}$, SNL80 mg/kg significantly reduced oxidative stress markers and restored antioxidant expression in a dose-dependent manner. Among these, the most significant improvements were observed in the Li60 $\mathrm{mg} / \mathrm{kg}$ alone and Li60 $\mathrm{mg} / \mathrm{kg}$ in combination with SNL80 mg/ $\mathrm{kg}$ treated groups, which were more effective than the SNL80 mg/kg and SNL40 mg/kg treated groups in significantly reducing oxidative stress markers and restoring antioxidant expression. (Table 6) 
Table 6

Neuroprotective potential of solanesol on oxidative stress markers level in ouabain-induced bipolar disorder in rats

\begin{tabular}{|c|c|c|c|c|c|c|c|}
\hline \multirow[t]{3}{*}{ S.no. } & \multirow[t]{3}{*}{ Groups } & \multicolumn{6}{|c|}{ Oxidative stress markers } \\
\hline & & AchE & LDH & SOD & GSH & Nitrite & MDA \\
\hline & & $\begin{array}{l}\text { (|varvec } \mu \\
\text { M/mg protein) }\end{array}$ & $\begin{array}{l}\text { ( } \mu \mathrm{M} / \mathrm{mg} \\
\text { protein) }\end{array}$ & $\begin{array}{l}\text { ( } \mu \mathrm{M} / \mathrm{mg} \\
\text { protein) }\end{array}$ & $\begin{array}{l}\text { ( } \mu \mathrm{M} / \mathrm{mg} \\
\text { protein) }\end{array}$ & $\begin{array}{l}\text { ( } \mu \mathrm{M} / \mathrm{mg} \\
\text { protein) }\end{array}$ & $\begin{array}{l}\text { (nM/mg } \\
\text { protein) }\end{array}$ \\
\hline 1. & $\begin{array}{l}\text { Vehicle } \\
\text { control }\end{array}$ & $18.61 \pm 0.618$ & $\begin{array}{l}100.40 \pm \\
1.523\end{array}$ & $\begin{array}{l}390.30 \pm \\
1.431\end{array}$ & $\begin{array}{l}29.97 \pm \\
0.781\end{array}$ & $\begin{array}{l}5.28 \pm \\
0.075\end{array}$ & $\begin{array}{l}27.87 \pm \\
0.665\end{array}$ \\
\hline 2. & $\begin{array}{l}\text { Sham } \\
\text { control }\end{array}$ & $17.82 \pm 0.523$ & $\begin{array}{l}101.00 \pm \\
1.560\end{array}$ & $\begin{array}{l}389.70 \pm \\
1.452\end{array}$ & $\begin{array}{l}29.99 \pm \\
0.785\end{array}$ & $\begin{array}{l}5.32 \pm \\
0.050\end{array}$ & $\begin{array}{l}27.89 \pm \\
0.519\end{array}$ \\
\hline 3. & $\begin{array}{l}\text { SNL80 } \\
\text { perse }\end{array}$ & $18.38 \pm 0.545$ & $\begin{array}{l}100.10 \pm \\
1.155\end{array}$ & $\begin{array}{l}390.30 \pm \\
1.621\end{array}$ & $\begin{array}{l}29.98 \pm \\
0.721\end{array}$ & $\begin{array}{l}5.21 \pm \\
0.065\end{array}$ & $\begin{array}{l}27.90 \pm \\
0.818\end{array}$ \\
\hline 4. & OUA & $45.11 \pm 0.639 \star$ & $\begin{array}{l}326.60 \pm \\
1.423^{*}\end{array}$ & $\begin{array}{l}268.60 \pm \\
1.532^{\star}\end{array}$ & $\begin{array}{l}8.21 \pm \\
0.594^{\star}\end{array}$ & $\begin{array}{l}10.29 \pm \\
0.069 *\end{array}$ & $\begin{array}{l}61.37 \pm \\
0.577^{\star}\end{array}$ \\
\hline 5. & $\begin{array}{l}\text { OUA + } \\
\text { SNL40 }\end{array}$ & $39.83 \pm 0.404^{\#}$ & $\begin{array}{l}296.10 \pm \\
1.538^{\#}\end{array}$ & $\begin{array}{l}285.50 \pm \\
1.404^{\#}\end{array}$ & $\begin{array}{l}14.08 \pm \\
0.346^{\#}\end{array}$ & $\begin{array}{l}9.22 \pm \\
0.071^{\#}\end{array}$ & $\begin{array}{l}52.76 \pm \\
0.796^{\#}\end{array}$ \\
\hline 6. & $\begin{array}{l}\text { OUA+ } \\
\text { SNL80 }\end{array}$ & $\begin{array}{l}34.52 \pm \\
0.480^{\# \$}\end{array}$ & $\begin{array}{l}246.00 \pm \\
1.511^{\# \$}\end{array}$ & $\begin{array}{l}315.40 \pm \\
1.630^{\# \$}\end{array}$ & $\begin{array}{l}17.27 \pm \\
0.349^{\# \$}\end{array}$ & $\begin{array}{l}8.24 \pm \\
0.056^{\# \$}\end{array}$ & $\begin{array}{l}45.15 \pm \\
0.618^{\# \$}\end{array}$ \\
\hline 7. & OUA + Li60 & $\begin{array}{l}29.66 \pm \\
0.442^{\# \beta}\end{array}$ & $\begin{array}{l}195.40 \pm \\
1.519^{\# \beta}\end{array}$ & $\begin{array}{l}345.20 \pm \\
1.262^{\# \beta}\end{array}$ & $\begin{array}{l}20.24 \pm \\
0.275^{\beta}\end{array}$ & $\begin{array}{l}7.21 \pm \\
0.586^{\# \beta}\end{array}$ & $\begin{array}{l}37.95 \pm \\
0.721^{\# \beta}\end{array}$ \\
\hline 8. & $\begin{array}{l}\text { OUA + } \\
\text { SNL80 + } \\
\text { Li60 }\end{array}$ & $\begin{array}{l}24.73 \pm \\
0.457^{\# @}\end{array}$ & $\begin{array}{l}144.80 \pm \\
1.337^{\# @}\end{array}$ & $\begin{array}{l}375.80 \pm \\
1.423^{\# @}\end{array}$ & $\begin{array}{l}23.31 \pm \\
0.297 \# @\end{array}$ & $\begin{array}{l}6.21 \pm \\
0.071^{\# @}\end{array}$ & $\begin{array}{l}31.14 \pm \\
0.612^{\# @}\end{array}$ \\
\hline $\begin{array}{l}\text { Statist } \\
\text { SEM ( } \\
\text { V/s OL } \\
\text { Li60 }\end{array}$ & analysis & $\begin{array}{l}\text { wed by one- } \\
\text { p). }{ }^{*} p<0.001 \\
\end{array}$ & $\begin{array}{l}\text { NOVA } \\
\text { ehicle }\end{array}$ & $\begin{array}{l}\text { oc Tuk } \\
\text { l, shan }\end{array}$ & $\begin{array}{l}\text { st). V } \\
\text { rol an } \\
00 \text { anc }\end{array}$ & $\begin{array}{l}\text { xpres: } \\
0 \text { per }\end{array}$ & $\begin{array}{l}\text { s mean } \pm \\
p<0.001 \\
\text { @ OUA + }\end{array}$ \\
\hline
\end{tabular}

\subsection{Discussion}

During the past decade, there has been significant progress in understanding the role of sirtuins in brain aging, neurodegenerative disorders such as $A D, P D, M S, A L S$, and neuropsychiatric disorders such as BD (Jęśko and Strosznajder, 2016; Yuan et al., 2016). Till now, relatively little is known about the role of SIRTs in PD (Tang, 2016), HD (Duan, 2013), and MS (Sharma et al., 2021). SIRT-1 expression and activity may significantly affect the course of AD pathology and may be a promising therapeutic target (Kupis et al., 2016). SIRT-1 inhibition impairs behavioral impairment, neurochemical changes, and brain cell damage (Shah et al., 2017; Lima et al., 2017). SIRT-1 downregulation involves various events related to higher brain dvsfunction includina svnantic dvsfunction, altered neurotransmitter secretion, and genetic variants Loading [MathJax]/jax/output/CommonHTML/jax.js 
(Fujita Yamashita, 2018). A previous study reported that no pharmacological animal model mimics mania and depression in the same animals (Logan et al., 2016). But Valvassori et al. established a model of single ICV injection of OUA elicited manic and depressive-like behaviour. The animals were treated to forced swimming in order to assess depressive-like behaviour (Valvassori et al., 2019).

Manic behaviours in rats, such as increased locomotor activity, rearing, and crossing, have been observed in several studies following ICV injection of OUA (Lopes-Borges et al., 2015; Valvassori et al., 2017). We discovered the same thing in our present study. The locomotor activity, number of boxes crossed, number of rearing movements, and time spent at the centre increased significantly after three days (1st, 3rd, and 7th) of protocol treatment in ICV-OUA induced BD rats. Also, the current study demonstrated manic and depressive-like behaviours in the same animal following a single OUA administration. As a result, the purpose of this study is to demonstrate OUA-induced contradictory behaviours in the same animal, and the SNL can prevent the BD-like behavioral, neurochemical and morphological alterations in OUA-induced $\mathrm{BD}$ in rats via upregulation of SIRT-1 signaling.

Compared to the normal control, vehicle control, and SNL80 perse groups, the animals did not show any behavioral changes in the open field test, forced swimming, and locomotor activity after OUA administration. As a result, it's possible that nine days following OUA injection, rats experience a calm episode (Valvassori et al., 2019; Wang et al., 2018; Kirshenbaum et al., 2011). The variance between experiments could be explained by differences in rat strains and experimental conditions. In the current study, the protocol was repeated for biochemical analysis, and we obtained identical results in the openfield test, with no behavioral changes. The concept of euthymia includes a stable period with no mood changes and an intra-state interval during which the patient does not exhibit enough mood symptoms to be categorized in a specific mood episode (Fava \& Bech, 2016).

Seven days of lithium pretreatment reduced OUA-induced manic-like behaviour. Several investigations from our group and others show that lithium therapy can correct manic-like behaviour in rats subjected to OUA-ICV injection (El-Mallakh et al., 2003, Jornada et al., 2011). Lithium administration, on the other hand, partially reversed the immobility time. Although earlier preclinical studies have revealed lithium antidepressant effects (Silva et al., 2008; Mohsen et al., 2017), and current investigation mimicked the maintenance treatment of depression and manic-like behaviours in a prospective BD animal model.

The construction of an animal model of BD produced by OUA is based on the hypothesis that a decrease in $\mathrm{Na}+/ \mathrm{K}+-\mathrm{ATP}$ ase activity is critical in the onset of manic and depressed mood episodes (Valvassori et al., 2019; Riegel et al., 2009). To validate that the dose of OUA used here reduces $\mathrm{Na}+/ \mathrm{K}+-\mathrm{ATP}$ ase activity, this enzyme activity was measured in the brains of rats. OUA lowered $\mathrm{Na}+/ \mathrm{K}+-\mathrm{ATP}$ ase activity in the whole brain of the mice seven and nine days after ICV injection. More than 50 years ago, the idea of $\mathrm{Na}+/ \mathrm{K}+-$ ATPase in BD physiopathology was proposed (Vitezić et al., 2008). A meta-analysis study found that $\mathrm{Na}+/ \mathrm{K}+-$ ATPase activity is reduced in BD patients' erythrocytes (Omar et al., 2017). Even a minor decrease in this enzyme activity may bring the resting membrane potential close to the threshold, increacinn nournnal excitahility and clnwing the rate of Ca2 + depuration (Lu et al., 2010). Hyperactivity, Loading [MathJax]/jax/output/CommonHTML/jax.js

Page 24/43 
which defines manic episodes in BD, could be triggered by increased neural excitability. Long-term $\mathrm{Na}+/ \mathrm{K}+-$ ATPase inhibition, which increases neuronal excitability, may decrease resting potential regulation, making subsequent neuronal depolarization more difficult. These events may diminish neuronal transmission velocity and, as a result, synaptic effectiveness of neurons, resulting in BD depressive episodes (Herman et al., 2007). Enhancement of $\mathrm{Na}+\mathrm{K}+-$ ATPase activity could be one of lithium's therapeutic methods against oxidative damage. Oxidative damage was reported in rats given OUA, resembling pathophysiological features in BD patients. Indeed, decreased anti-oxidant glutathione enzymes in the brain have been found in animal models of mania and depression (Budni et al., 2013). Modulation of these anti-oxidant enzymes, which contributes to preserving redox equilibrium in the brain, is one of the lithium's probable therapeutic activities (Muneer et al., 2016). According to one study, decreased activity of $\mathrm{Na}+/ \mathrm{K}+-\mathrm{ATP}$ ase found in BD patients could be linked to increased secretion of dopamine and glutamate hormones as well as oxidative damage, resulting in mood swings (Sigitova et al., 2017).

As a mood stabilizer, lithium works to reverse these pathological alterations, which helps to alleviate BD symptoms. The proposed OUA model could be employed to research the disorder's pathogenesis and the screening of promising mood stabilizer medication candidates. Chronic treatment of OUA to the brain resulted in decreased ATP cell generation, increased oxidative stress-mediated by ROS and RNS, glial cell overactivation, and lower regulation of SIRT-1 protein, in addition to reduced ATP cell production (Valvassori et al., 2019). SIRT-1 deacetylation depends on NAD + and ATP synthesis in cells and regulates its amount in mitochondria and other parts of the brain. Memory impairment is also caused by SIRT-1 dysregulation, and oxidative markers have been utilized to identify the excessive production of ROS and RNS in the brain (Shin et al., 2015). In bipolar patients, an increase in oxidative stress has been linked to a decrease in the activity of the Na+/K+-ATPase (Valvassori et al., 2015).

According to current research, OUA-treated rats saw decreased independent body weight on days 14th, $21 \mathrm{st}$, and 28th. Furthermore, there was an increase in locomotor activity in the actophotometer on days 9th, 18th, and 27th, responsible for manic-like behaviour. OFT observed this manic-like activity on days 7th, 14th, 21st, and 28th, indicating a progressive increase in the number of rearing, number of boxes crossing, and time spent in the center. Further FST on the 9th, 18th, and 27th days indicated an improvement in immobility time.

The effect of OUA on the protein level of SIRT-1 in the brain is being explored in this study. This suggests a decrease in SIRT-1 protein levels. Furthermore, the levels of apoptotic markers Caspase-3, Bax, and Bcl-2 were evaluated, and OUA-treated rats had higher levels of caspase-3, Bax, and lower levels of Bcl-2. In contrast, the downregulation of mitochondrial ETC complex enzymes has been linked to a significant increase in inflammatory cytokines TNF- $\alpha$ and IL-1 $\beta$. The study shows that when rats are persistently treated with OUA, the amount of neurotransmitters changes. Neurotoxic effects in rats are indicated by decreased serotonin and acetylcholine levels and increased dopamine and glutamate levels. Oxidative damage is a major factor in neurodegenerative disorders. OUA treatment causes a significant increase in reasing SOD and GSH. 
Our research found that twenty days of chronic treatment of SNL40, $80 \mathrm{mg} / \mathrm{kg}$ in ICV injection to OUAtreated rats, resulted in a considerable improvement in body weight by the 21 st day of the protocol. Furthermore, there was a 5-minute decrease in locomotor activity in the actophotometer. The high doseresponse of SNL indicates a considerable reduction in behavioural activities, and the standard drug lithium alone and in combination with SNL high dose also exhibited a marked decline in behavioural parameters activity than SNL treated rats.

SIRT-1 levels rise after chronic treatment of SNL40 and SNL80 mg/ $\mathrm{kg}$, and SIRT-1 is activated in CSF, brain homogenate, and blood plasma samples, according to this study. In addition, Li-treated groups were more efficient than SNL-treated groups in recovering SIRT-1 protein expression in rat brain homogenate, blood plasma, and CSF samples. However, in blood plasma and brain homogenate, the apoptotic marker level reveals a drop in caspase-3, Bax, and a rise in Bcl-2. Furthermore, results reveal that continuous SNL treatment restores mitochondrial complexes such as Complex I, II, IV, and V and CoQ10 in brain homogenate. TNF- $\alpha$ and IL-1 $\beta$ levels in blood plasma and rat brain homogenate samples suggest that SNL treatment reduces neuronal inflammation. In addition, at all doses, SNL boosted serotonin and acetylcholine levels while decreasing dopamine and glutamate levels in rat brain homogenate.

Oxidative damage in OUA-treated rats treated with SNL40 and $80 \mathrm{mg} / \mathrm{kg}$, on the other hand, reflects a reduction in oxidative stress through a significant drop in the levels of AchE, MDA, LDH, and nitrite levels. As well as a considerable increase in the quantity of anti-oxidant markers SOD and GSH in brain homogenate. In blood plasma and bairn homogenate samples, the Li60 mg/kg alone and Li60 mg/kg in conjunction with SNL80 mg/kg treated groups were more efficient than the SNL80 mg/kg SNL40 mg/kg treated groups in restoring the altered levels of biochemical parameters.

As a result, the current work finds that following ICV-OUA insertion in rats, SIRT-1 signaling and neuronal death are reduced. In addition, there was a depletion of mitochondrial ETC complexes in the case of the disease and an increase in inflammation and oxidative stress. Chronic treatment with SNL and Li causes changes and results in significant dose-dependent restorations. Consequently, these SIRT-1 presences and their SNL activators had a neuroprotective impact on OUA-mediated BD rat model ICV injections.

Although the current data are only associations, they show that SNL reduced the downregulation of SIRT1 signaling in rats with BD-like behavioral and neurochemical symptoms in OUA-induced BD. Our results indicate that SIRT-1 levels can be employed for predicting a major brain degenerative component in brain tissue, blood plasma, and CSF as an effective and reliable early diagnostic biomarker. Lithium works as a mood stabilizer medicine to counteract these pathological alterations that help mitigate symptoms of BD. The proposed OUA model could be applied to investigate disease pathophysiology and the screening of prospective medication candidates for mood stabilizers.

Overall, a mechanistic approach must be verified using knock-in or knock-out examinations of the sirtuin genes. Additionally, correlative analysis, such as Western Blot for cellular markers, is required to provide molecular support for this idea. Even following these disadvantages, the potential in brain

Loading [MathJax]/jax/output/CommonHTML/jax.js

Page 26/43 
downregulatory SIRT-1 signaling cascades of the neuroprotective component of SNL has been identified to develop a new disease-modifying medication for this neurodegenerative disease.

\subsection{Conclusion}

In conclusion, the study shows that SNL protects rats from developing BD caused by OUA. This is the first study to link the antioxidants, anti-inflammatory, and anti-apoptotic capabilities of SNL to its potential neuroprotective effect as a drug for the treatment and management of BD. The amount of different neurochemicals in brain homogenate, blood plasma, and CSF was measured, demonstrating that SNL had a protective effect both centrally and peripherally by attenuating BD-like changes.

The findings suggest that this study can be utilized as strong evidence that SIRT-1 downregulation and serotonin evaluation can be used as a potential biomarker for the early identification of BD. The absence of gross pathology and immunohistology research on the area-specific molecular mechanistic effect of SNL is the major drawback of this study. As a result, more preclinical investigations on the knock-in and knock-out of the SIRT-1 gene are needed to understand the molecular mechanism better.

\section{Abbreviations}

SIRT-1 : : : : $\quad$ ilent mating-type information regulation 2 homolog-1

NAD+ $\quad$ :Nicotinamide adenine dinucleotide

BD :Bipolar Disorder

IL-1 $\quad$ :Interleukin-1 $\beta$

AD :Alzheimer disease

PD :Parkinson's disease

MS :Multiple sclerosis

NADH :Nicotinamide adenine dinucleotide hydrogen

p53 :Tumour proteins p53

F0X01/3 :Fork head box protein 01/3

PGC-1 :Peroxisome proliferator-activated gamma co-activator-1

NF-kB : :Nuclear factor kappa light chain enhancer of activated B-cells

Na+K+-ATPase :Sodium and potassium-activated adenosine triphosphatase 
ALS

TNF- $a$

AP-1

ROS

RNS

BDNF

ATP

BAX

ERK1/2

CVS

AchE

CSF

FST

GSH

HPLC

LDH

MDA

v/v

SNL

ICV

OUA

CoQ10
:Amyotrophic lateral sclerosis

:Tumour necrosis factor-alpha

:Activator protein-1

:Reactive oxygen species

:Reactive nitrogen species

:Brain-derived neurotrophic factor

:Adenosine triphosphate

:Bcl-2-associated X protein

:Extracellular signaling-regulated protein kinases 1 \&2

:Chronic variable stress

:Acetylcholinesterase

:Cerebrospinal fluid

: Forced Swim test

:Glutathione

:High performance liquid chromatography

:Lactate dehydrogenase

:Malondialdehyde

:volume/volume

:solanesol

:Intracerebroventricular

:Ouabain

:Coenzyme Q10

:Lithium 
ETC

HD

ALS

ICH

IAEC

BAPEX

SEM

ANOVA

MDA

SOD

LDH

OFT

Ca2+

Ach

FST

IP

ELISA

SDH

PO

OPA/ $\beta-M E$
:Electron transport chain

:Huntington disease

:Amyotrophic lateral sclerosis

:Intracerebral haemorrhage

:Institutional AnimalEthics Committee

:Bangladesh Petroleum Exploration and Production

:Standard error of the mean

:Analysis of variance

:malondialdehyde

:superoxide dismutase

:lactate dehydrogenase

:Open field test

:Calcium

:Acetylcholine

:Force swim test

:Intraperitoneal

:Enzyme-linked immunoassay

:Succinatedehydrogenase

:Per oral

:O-phthalaldehyde/ $\beta$-mercaptoethanol

\section{Declarations}

\section{Acknowledgments}

The authors express their gratitude to Chairman, Mr. Parveen Garg, and Director, Dr. G.D.Gupta, ISF College of Pharmacy, Moga (Punjab), India, for their excellent vision and support. 


\section{Author contributions}

The authors declare that all data were generated in-house and that no paper mill was used. Bidisha Rajkhowa (BR) contributed thesis research work, Performed experimental animal studies, Compilation of statistical research data; Sidharth Mehan (SM) contributed original research hypothesis, guide, and compilation of all manuscript data

\section{Ethical approval}

All applicable institutional guidelines for the care and use of animals were followed.

\section{Consent to participate}

Not applicable

\section{Consent to publish}

Not applicable

\section{Funding}

This work was supported by Government of India, the experimental procedure was approved by the Institutional AnimalEthics Committee (IAEC) with a registration number.816/PO/ReBiBt/S/04/CPCSEA as protocol no. ISFCP/IAEC/CPCSEA/Meeting No: 28/2020/Protocol No.463.

\section{Competing Interests}

"The authors declare no conflict of interest." "The funders had no role in the design of the study; in the collection, analyses, or interpretation of data; in the writing of the manuscript, or in the decision to publish the results".

\section{Availability of data and materials}

All data generated or analyzed during this study are included in this article. There are no separate or additional files.

\section{References}

Aguirre-Rueda, D., Guerra-Ojeda, S., Aldasoro, M., Iradi, A., Obrador, E., Ortega, A., Mauricio, M.D., Vila, J.M., and Valles, S.L., 2015. Astrocytes protect neurons from AB1-42 peptide-induced neurotoxicity increasing TFAM and PGC-1 and decreasing PPAR- $y$ and SIRT-1. International journal of medical sciences, 12(1), 48.

Alageel A, Tomasi J, Tersigni C, Brietzke E, Zuckerman H, Subramaniapillai M, Lee Y, lacobucci M, Rosenblat JD, Mansur RB, Mclntyre RS. Evidence supporting a mechanistic role of sirtuins in mood and 
metabolic disorders. Progress in Neuro-Psychopharmacology and Biological Psychiatry. 2018 Aug 30;86:95-101.

Alam MM, Mehan S. EFFECT OF FORSKOLIN IN COMBINATION WITH SOLANESOL IN METHYL MERCURY INDUCED EXPERIMENTAL MODEL OF AMYOTROPHIC LATERAL SCLEROSIS IN RATS. International Journal of Pharmacy \& Life Sciences. 2019 Jun 1;10(6).

Alam MM, Minj E, Yadav RK, Mehan S. Neuroprotective potential of adenyl cyclase/cAMP/CREB and mitochondrial CoQ10 activator in amyotrophic lateral sclerosis rats. Curr. Bioact. Compd. 2020;16:1-8.

Alcendor RR, Gao S, Zhai P, Zablocki D, Holle E, Yu X, Tian B, Wagner T, Vatner SF, Sadoshima J. Sirt1 regulates aging and resistance to oxidative stress in the heart. Circulation research. 2007 May 25;100(10):1512-21.

Baldo B, Gabery S, Soylu-Kucharz R, Cheong RY, Henningsen JB, Englund E, et al. SIRT1 is increased in affffected brain regions and hypothalamic metabolic pathways are altered in Huntington disease. Neuropathol Appl Neurobiol. (2018) doi: 10.1111/nan.12514. [Epub ahead of print].

Banerjee U, Dasgupta A, Rout JK, Singh OP. Effects of lithium therapy on Na+-K+-ATPase activity and lipid peroxidation in bipolar disorder. Progress in Neuro-Psychopharmacology and Biological Psychiatry. 2012 Apr 27;37(1):56-61.

Bartoli-Leonard, F., Wilkinson, F.L., Schiro, A. et al. Suppression of SIRT1 in Diabetic Conditions Induces Osteogenic Differentiation of Human Vascular Smooth Muscle Cells via RUNX2 signaling. Sci Rep 9, 878 (2019). https://doi.org/10.1038/s41598-018-37027-2.

Budni, J. et al. Folic acid prevents depressive-like behavior and hippocampal antioxidant imbalance induced by restraint stress in mice. Exp. Neurol. 240, 112-121 (2013).

C. L. Ferland, W. R. Hawley, R. E. Puckett et al., "Sirtuin activity in dentate gyrus contributes to chronic stress-induced behavior and extracellular signal-regulated protein kinases 1 and 2 cascade changes in the hippocampus," Biological Psychiatry, vol. 74, no. 12, pp. 927-935, 2013.

Cantó, Carles et al. "AMPK regulates energy expenditure by modulating NAD+ metabolism and SIRT1 activity." Nature vol. 458,7241 (2009): 1056-60. doi:10.1038/nature07813.

Decker, S., Grider, G., Cobb, M., LI, X.-P., Huff, M. O., El-Mallakh, R. S., \& Levy, R. S. (2000). Open field is more sensitive than automated activity monitor in documenting ouabain-induced hyperlocomotion in the development of an animal model for bipolar illness. Progress in Neuro-Psychopharmacology and Biological Psychiatry, 24(3), 455-462. doi:10.1016/s0278-5846(99)00111-6

Deshmukh R, Sharma V, Mehan S, Sharma N, Bedi KL. Amelioration of intracerebroventricular streptozotocin induced cognitive dysfunction and oxidative stress by vinpocetine-a PDE1 inhibitor. Loading [MathJax]/jax/output/CommonHTML/jax.js :t 12;620(1-3):49-56. 
Donmez, G., and Outeiro, T.F., 2013. SIRT1 and SIRT2: emerging targets in neurodegeneration. EMBO molecular medicine, 5(3), pp.344-352.

Duan W (2013) Targeting sirtuin-1 in Huntington's disease: rationale and current status. CNS Drugs 27:345-352. doi:10.1007/s40263-013-0055-0.

Dudi R, Mehan S. Neuroprotection of brain permeable Forskolin ameliorates behavioral, biochemical and histopatho-logical alterations in rat model of intracerebral hemorrhage. Pharmaspire. 2018;10:68-86.

Elibol B, Kilic U. High levels of SIRT1 expression as a protective mechanism against disease-related conditions. Frontiers in endocrinology. 2018 Oct 15;9:614.

El-Mallakh, R. S. \& Wyatt, R. J. The Na,K-ATPase hypothesis for bipolar illness. Biol. Psychiatry 37, 235244 (1995).

El-Mallakh, R. S. \& Wyatt, R. J. The Na,K-ATPase hypothesis for bipolar illness. Biol. Psychiatry 37, 235244 (1995).

El-Mallakh, R. S. et al. Intracerebroventricular administration of ouabain as a model of mania in rats. Bipolar Disord. 5, 362-365 (2003).

El-Mallakh, R. S. The Na,K-ATPase hypothesis for manic-depression. I. General considerations. Med. Hypotheses 12, 253-268 (1983).

Faizi, M., Seydi, E., Abarghuyi, S., Salimi, A., Nasoohi, S., Pourahmad, J., 2016. A search for mitochondrial damage in Alzheimer's disease using isolated rat brain mitochondria. Iranian journal of pharmaceutical research: IJPR, 15(1), 185.

Fava, G. A. \& Bech, P. The concept of euthymia. Psychother. Psychosom. 85, 1-5 (2016).

Forester BP, Harper DG, Georgakas J, Ravichandran C, Madurai N, Cohen BM. Antidepressant effects of open label treatment with coenzyme Q10 in geriatric bipolar depression. J Clin Psychopharmacol. 2015 Jun;35(3):338-40. doi: 10.1097/JCP.0000000000000326. PMID: 25874916; PMCID: PMC4414830.

Fujita Y and Yamashita T (2018) Sirtuins in Neuroendocrine Regulation and Neurological Diseases. Front. Neurosci. 12:778. doi: 10.3389/fnins.2018.00778

Herman, L., Hougland, T. \& El-Mallakh, R. S. Mimicking human bipolar ion dysregulation models mania in rats. Neurosci. Biobehav. Rev. 31, 874-881 (2007).

Herskovits AZ, Guarente L. SIRT1 in neurodevelopment and brain senescence. Neuron. 2014 Feb 5;81(3):471-83. doi: 10.1016/j.neuron.2014.01.028. PMID: 24507186; PMCID: PMC4040287.

Jamali-Raeufy, N., Mojarrab, Z., Baluchnejadmojarad, T., Roghani, M., Fahanik-Babaei, J. and Goudarzi, Loading [MathJax]/jax/output/CommonHTML/jax.js n of dipeptidyl peptidase-4 and P2X7 purinoceptors in an in 
vivo Parkinson's disease model. Metabolic Brain Disease, 35(3), pp.539-548.

Jęśko H, Strosznajder RP (2016) Sirtuins and their interactions with transcription factors and poly(ADPribose) polymerases. Folia Neuropathol 54:212-233

Joas E, Karanti A, Song J, Goodwin GM, Lichtenstein P, Landen M. Pharmacological treatment and risk of psychiatric hospital admission in bipolar disorder. The British Journal of Psychiatry. 2017 Mar;210(3):197-202.

Jornada, L. K. et al. Lithium and valproate modulate antioxidant enzymes and prevent ouabain-induced oxidative damage in an animal model of mania. J. Psychiatr. Res. 45, 162-168 (2011).

Jornada, L. K. et al. Lithium and valproate modulate antioxidant enzymes and prevent ouabain-induced oxidative damage in an animal model of mania. J. Psychiatr. Res. 45, 162-168 (2011).

Kapoor T, Mehan S. EFFECT OF FORSKOLIN IN INTRACEREBROPEDUNCLE ETHIDIUM BROMIDE INDUCED EXPERIMENTAL MODEL OF MULTIPLE SCLEROSIS IN RATS. International Journal of Pharmacy \& Life Sciences. 2019 Jun 1;10(6).

Khera $\mathrm{H}$, Awasthi A, Mehan S. Myocardial preconditioning potential of hedgehog activator purmorphamine (smoothened receptor agonist) against ischemia-reperfusion in deoxycortisone acetate salt-induced hypertensive rat hearts. Journal of Pharmacology and Pharmacotherapeutics. 2019 Apr 1;10(2):47.

Kirshenbaum GS, Clapcote SJ, Duffy S, Burgess CR, Petersen J, Jarowek KJ, Yücel YH, Cortez MA, Snead OC, Vilsen B, Peever JH. Mania-like behavior induced by genetic dysfunction of the neuron-specific $\mathrm{Na}+$, K+-ATPase a3 sodium pump. Proceedings of the National Academy of Sciences. $2011 \mathrm{Nov}$ 1;108(44):18144-9.

Kumar N, Sharma N, Khera R, Gupta R, Mehan S. Guggulsterone ameliorates ethidium bromide-induced experimental model of multiple sclerosis via restoration of behavioral, molecular, neurochemical and morphological alterations in rat brain. Metabolic Brain Disease. 2021 Jun;36(5):911-25.

Kupis W, Pałyga J, Tomal E, Niewiadomska E (2016) The role of sirtuins in cellular homeostasis. J Physiol Biochem 72:371 - 380. doi:10.1007/s13105-016-0492-6

Ladol S, Sharma D. Pharmacotherapeutic Effects of Hippophae rhamnoides in Rat Model of Posttraumatic Epilepsy in View of Oxidative Stress, $\mathrm{Na}+\mathrm{K}+$ ATPase Activity and Sodium lon Channel Expression. Acta Scientific Neurology (ISSN: 2582-1121). 2021 Jun;4(6).

Li K, Lv G, Pan L. Sirt1 alleviates LPS induced inflammation of periodontal ligament fibroblasts via downregulation of TLR4. Int J Biol Macromol. (2018) 119:249-54. doi: 10.1016/j.ijbiomac.2018.07.099 
Li X.H., Chen C., Tu Y., Sun H.T., Zhao M.L., Cheng S.X., Qu Y., Zhang S.SIRT-1 promotes axonogenesis by deacetylation of Akt and inactivation of GSK3.Mol.Neurobiol.2013; 48: 490-499.

Lima, L.C.F., Saliba, S.W., Andrade, J.M.O., Cunha, M.L., Cassini-Vieira, P., Feltenberger, J.D., Barcelos, L.S., Guimarães, A.L.S., de-Paula, A.M.B., de Oliveira, A.C.P. and Santos, S.H.S., 2017. Neurodegeneration alters metabolic profile and Sirt 1 signaling in high-fat-induced obese mice. Molecular neurobiology, 54(5), 3465-3475.

Logan RW, McClung CA. Animal models of bipolar mania: The past, present and future. Neuroscience. 2016 May 3;321:163-188. doi: 10.1016/j.neuroscience.2015.08.041. Epub 2015 Aug 24. PMID: 26314632; PMCID: PMC4766066.

Lopes-Borges, J. et al. Histone deacetylase inhibitors reverse manic-like behaviors and protect the rat brain from energetic metabolic alterations induced by ouabain. Pharm. Biochem Behav. 128, 89-95 (2015).

Lopes-Borges, J. et al. Histone deacetylase inhibitors reverse manic-like behaviors and protect the rat brain from energetic metabolic alterations induced by ouabain. Pharm. Biochem Behav. 128, 89-95 (2015).

Lu B, Zhang Q, Wang H, Wang Y, Nakayama M, Ren D. Extracellular calcium controls background current and neuronal excitability via an UNC79-UNC80-NALCN cation channel complex. Neuron. 2010 Nov 4;68(3):488-99. doi: 10.1016/j.neuron.2010.09.014. PMID: 21040849; PMCID: PMC2987630.

Mariani S, di Giorgio MR, Martini P, Persichetti A, Barbaro G, Basciani S, Contini S, Poggiogalle E, Sarnicola A, Genco A, Lubrano C. Inverse association of circulating SIRT1 and adiposity: a study on underweight, normal weight, and obese patients. Frontiers in endocrinology. 2018 Aug 7;9:449.

McCarthy MJ, Liang S, Spadoni AD, Kelsoe JR, Simmons AN (2014) Whole Brain Expression of Bipolar Disorder Associated Genes: Structural and Genetic Analyses. PLoS ONE 9(6): e100204. doi:10.1371/journal.pone.0100204.

McGuffin P, Rijsdijk F, Andrew M, Sham P, Katz R, et al. (2003) The heritability of bipolar affective disorder and the genetic relationship to unipolar depression. Arch Gen Psychiatry 60: 497-502.

Mclnerney SJ, Kennedy SH. Review of evidence for use of antidepressants in bipolar depression. Prim Care Companion CNS Disord. 2014:16.

Mehan S, Meena H, Sharma D, Sankhla R. JNK: a stress-activated protein kinase therapeutic strategies and involvement in Alzheimer's and various neurodegenerative abnormalities. Journal of Molecular Neuroscience. 2011 Mar;43(3):376-90.

Mehan S, Monga V, Rani M, Dudi R, Ghimire K. Neuroprotective effect of solanesol against 3Loading [MathJax]/jax/output/CommonHTML/jax.js ease-like behavioral, biochemical, and cellular alterations: 
Restoration of coenzyme-Q10-mediated mitochondrial dysfunction. Indian journal of pharmacology. 2018 Nov;50(6):309.

Mehan S, Rahi S, Tiwari A, et al. Adenylate cyclase activator forskolin alleviates intracerebroventricular propionic acid-induced mitochondrial dysfunction of autistic rats. Neural Regen Res. 2020;15(6):11401149. doi:10.4103/1673-5374.270316.

Mehan S, Rahi S, Tiwari A, Kapoor T, Rajdev K, Sharma R, Khera H, Kosey S, Kukkar U, Dudi R. Adenylate cyclase activator forskolin alleviates intracerebroventricular propionic acid-induced mitochondrial dysfunction of autistic rats. Neural Regen Res. 2020 Jun;15(6):1140-1149. doi: 10.4103/16735374.270316. PMID: 31823895; PMCID: PMC7034277.

Mehan, S., Parveen, S., Kalra, S., 2017. Adenyl cyclase activator forskolin protects against Huntington's disease-like neurodegenerative disorders. Neural regeneration research, 12(2), 290.

Michan S, Sinclair D. Sirtuins in mammals: insights into their biological function. Biochem J. 2007;404(1):1-13. doi:10.1042/BJ20070140.

Mohseni, G. et al. Agmatine enhances the antidepressant-like effect of lithium in mouse forced swimming testthrough NMDA pathway. Biomed. Pharmac other. 88, 931-938 (2017).

Moneim AE. The neuroprotective effect of berberine in mercury-induced neurotoxicity in rats. Metabolic brain disease. 2015 Aug;30(4):935-42.

Monti JM. The effect of second-generation antipsychotic drugs on sleep parameters in patients with unipolar or bipolar disorder. Sleep medicine. 2016 Jul 1;23:89-96.

Mullins N, Forstner AJ, O'Connell KS, Coombes B, Coleman JR, Qiao Z, Als TD, Bigdeli TB, Børte S, Bryois J, Charney AW. Genome-wide association study of more than 40,000 bipolar disorder cases provides new insights into the underlying biology. Nature Genetics. 2021 Jun;53(6):817-29.

Muneer, A. The neurobiology of bipolar disorder: an integrated approach. Chonnam Med. J. 52, 18-37 (2016).

N. Abe-Higuchi, S. Uchida, H. Yamagata et al., "Hippocampal sirtuin 1 signaling mediates depression-like behavior," Biological Psychiatry, vol. 80, no. 11, pp. 815-826, 2016.

Nestler EJ, Hyman SE. Animal models of neuropsychiatric disorders. Nat Neurosci. 2010 Oct;13(10):11619. doi: 10.1038/nn.2647. Epub 2010 Sep 27. PMID: 20877280; PMCID: PMC3750731.

Nestler, E. J. \& Hyman, S. E. Animal models of neuropsychiatric disorders. Nat. Neurosci. 13, 1161-1169 (2010). 
Nillni EA. The metabolic sensor Sirt1 and the hypothalamus: interplay between peptide hormones and pro-hormone convertases. Mol Cell Endocrinol. (2016) 438:77-88 doi: 10.1016/j.mce.2016.09.002.

Omar AK, Ahmed KA, Helmi NM, Abdullah KT, Qarii MH, Hasan HE, Ashwag A, Nabil AM, Abdu AM, Salama MS. The sensitivity of Na+, K+ ATPase as an indicator of blood diseases. Afr Health Sci. 2017 Mar;17(1):262-269. doi: 10.4314/ahs.v17i1.32. PMID: 29026401; PMCID: PMC5636257.

Pisanu C, Heilbronner U, Squassina A. The role of pharmacogenomics in bipolar disorder: moving towards precision medicine. Molecular diagnosis \& therapy. 2018 Aug;22(4):409-20.

Pollard, A.K., Craig, E.L., Chakrabarti, L., 2016. Mitochondrial complex 1 activity measured by spectrophotometry is reduced across all brain regions in ageing and more specifically in neurodegeneration. PLoS One,11(6).

Rahi S, Gupta R, Sharma A, Mehan S. Smo-Shh signaling activator purmorphamine ameliorates neurobehavioral, molecular, and morphological alterations in an intracerebroventricular propionic acidinduced experimental model of autism. Human \& Experimental Toxicology. 2021 Apr 28:09603271211013456.

Rajdev K, Siddiqui EM, Jadaun KS, Mehan S. Neuroprotective potential of solanesol in a combined model of intracerebral and intraventricular hemorrhage in rats. IBRO reports. 2020 Jun 1;8:101-14.

Rana S, Singh L, Mehan S. Forskolin, ameliorates mitochondrial dysfunction in Streptozotocin induced diabetic nephropathy in rats. Asian Journal of Pharmacy and Pharmacology. 2019;5(1):199-206.

Schurr, A., Livne, A., 1976. Differential inhibition of mitochondrial monoamine oxidase from brain by hashish components. Biochemical pharmacology, 25(10), 1201-3.

Schwartz, M.W., Woods, S.C., Porte, D, Jr., Seeley, R.J., and Baskin, D.G., 2000. Central nervous system control of food intake. Nature, 404, 661-671. doi: 10.1038/35007534.

Shah, S.A., Khan, M., Jo, M.H., Jo, M.G., Amin, F.U. and Kim, M.O., 2017. Melatonin stimulates the SIRT $1 / \mathrm{Nrf2}$ signaling pathway counteracting lipopolysaccharide (LPS) -induced oxidative stress to rescue postnatal rat brain. CNS neuroscience \& therapeutics, 23(1), 33-44.

Sharma N, Upadhayay S, Shandilya A, Sahu R, Singh A, Rajkhowa B, Mehan S. Neuroprotection by solanesol against ethidium bromide-induced multiple sclerosis-like neurobehavioral, molecular, and neurochemical alterations in experimental rats. Phytomedicine Plus. 2021 Nov 1;1(4):100051.

Sharma R, Rahi S, Mehan S. Neuroprotective potential of solanesol in intracerebroventricular propionic acid induced experimental model of autism: Insights from behavioral and biochemical evidence. Toxicology reports. 2019 Jan 1;6:1164-75. 
Shin, B.K., Kwon, S.W. and Park, J.H., 2015. Chemical diversity of ginseng saponins from Panax ginseng. Journal of ginseng research, 39(4), 287-298.

Sigitova, E., Fišar, Z., Hroudová, J., Cikánková, T. \& Raboch, J. Biological hypotheses and biomarkers of bipolar disorder. Psychiatry Clin. Neurosci. 71, 77-103 (2017).

Silva, R. et al. Lithium blocks stress-induced changes in depressive-like behavior and hippocampal cell fate: the role of glycogen-synthase-kinase-3beta. Neuroscience 152, 656-669 (2008).

Singh P, Hanson PS, Morris CM. SIRT1 ameliorates oxidative stress induced neural cell death and is down-regulated in Parkinson's disease. BMC Neurosci. (2017) 18:46. doi: 10.1186/s12868-017-0364-1

Tang BL (2016) Sirtuins as modifiers of Parkinson's disease pathology. J Neurosci Res. doi:10.1002/jnr.23806 6.

Uher R, Zwicker A. Etiology in psychiatry: embracing the reality of poly-gene-environmental causation of mental illness. World Psychiatry. 2017 Jun;16(2):121-129. doi: 10.1002/wps.20436. PMID: 28498595; PMCID: PMC5428165.

Valvassori SS, Budni J, Varela RB, Quevedo J. Contributions of animal models to the study of mood disorders. Brazilian Journal of Psychiatry. 2013;35:S121-31.

Valvassori SS, Dal-Pont GC, Resende WR, Varela RB, Lopes-Borges J, Cararo JH, Quevedo J. Validation of the animal model of bipolar disorder induced by Ouabain: face, construct and predictive perspectives. Translational psychiatry. 2019 Jun 4;9(1):1-1.

Valvassori SS, Dal-Pont GC, Varela RB, Resende WR, Gava FF, Mina FG, Budni J, Quevedo J. Ouabain induces memory impairment and alter the BDNF signaling pathway in an animal model of bipolar disorder: Cognitive and neurochemical alterations in BD model. Journal of Affective Disorders. 2021 Mar 1;282:1195-202.

Valvassori SS, Resende WR, Lopes-Borges J, Mariot E, Dal-Pont GC, Vitto MF, Luz G, de Souza CT, Quevedo J. Effects of mood stabilizers on oxidative stress-induced cell death signaling pathways in the brains of rats subjected to the ouabain-induced animal model of mania: mood stabilizers exert protective effects against ouabain-induced activation of the cell death pathway. Journal of psychiatric research. 2015 Jun 1;65:63-70.

Valvassori, S. S. et al. Effects of mood stabilizers on oxidative stress-induced cell death signaling pathways in the brains of rats subjected to the ouabaininduced animal model of mania: mood stabilizers exert protective effects against ouabain-induced activation of the cell death pathway. J. Psychiatr. Res. 65, 63-70 (2015). Jornada, L. K. et al. Lithium and valproate modulate antioxidant enzymes and prevent ouabain-induced oxidative damage in an animal model of mania. J. Psychiatr. Res. 45, 162-168 (2011). 
Valvassori, S. S. et al. Lithium and valproate act on the GSK-3 $\beta$ signaling pathway to reverse manic-like behavior in an animal model of mania induced by ouabain. Neuropharmacology 117, 447-459 (2017).

Vitezić D, Pelcić JM, Zupan G, Vitezić M, Ljubicić D, Simonić A. NA+, K+-ATPase activity in the brain of the rats with kainic acid-induced seizures: influence of lamotrigine. Psychiatria Danubina. 2008 Sep 1;20(3):269-76.

Waddington, J. L., Kingston, T., Nkire, N., \& Russell, V. (2021). Major depressive disorder with psychotic features: Confronting and resolving the dimensional challenge. In C. A. Tamminga, E. I. Ivleva, U. Reininghaus, \& J. van Os (Eds.), Psychotic disorders: Comprehensive conceptualization and treatments (pp. 50-58). Oxford University Press.

Walker ER, McGee RE, Druss BG. Mortality in mental disorders and global disease burden implications: a systematic review and meta-analysis. JAMA Psychiatry 2015;72:334-41.

Wang YC, Yu YH, Tsai ML, Huang AC. Motor function in an animal model with ouabain-induced bipolar disorder and comorbid anxiety behavior. Psychiatry research. 2018 Oct 1;268:508-13.

Wu Z, Liu MC, Liang M, Fu J. Sirt1 protects against thrombomodulin down-regulation and lung coagulation after particulate matter exposure. Blood, The Journal of the American Society of Hematology. 2012 Mar 8;119(10):2422-9.

Yan, N., Liu, Y., Gong, D., Du, Y., Zhang, H., Zhang, Z., 2015. Solanesol: a review of its resources, derivatives, bioactivities, medicinal applications, and biosynthesis. Phytochem. Rev. 14, 403-417. https://doi.org/10.1007/s11101-015-9393-5.

Young, A.B., Snyder, S.H., 1974. Gamma-aminobutyric acid binding to receptor sites in the rat central nervous system. Proceedings of the National Academy of Sciences. 71(12), 4802-7.

Yu, H. S., Kim, S. H., Park, H. G., Kim, Y. S., \& Ahn, Y. M. Intracerebroventricular administration of ouabain, a $\mathrm{Na}$ /K-ATPase inhibitor, activates tyrosine hydroxylase through extracellular signal-regulated kinase in rat striatum. Neurochemistry International, 59(6), 779-786 (2011). doi:10.1016/j.neuint.2011.08.011

Yuan Y, Cruzat VF, Newsholme P et al (2016) Regulation of SIRT1 in aging: roles in mitochondrial function and biogenesis. Mech Ageing Dev 155:10-21. doi:10.1016/j.mad.2016.02.003

Zhou C, Wu Y, Ding X, Shi N, Cai Y, Pan ZZ. SIRT1 decreases emotional pain vulnerability with associated CaMKIla deacetylation in central amygdala. Journal of Neuroscience. 2020 Mar 11;40(11):2332-42.

Zhu L, Sun C, Ren J, Wang G, Ma R, Sun L, Yang D, Gao S, Ning K, Wang Z, Chen X. Stress-induced precocious aging in PD-patient iPSC-derived NSCs may underlie the pathophysiology of Parkinson's disease. Cell death \& disease. 2019 Feb 4;10(2):1-7. 


\section{Figures}

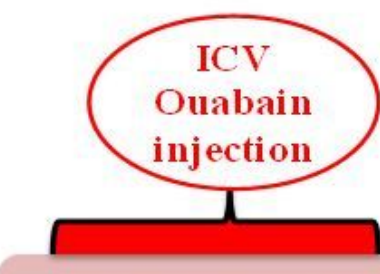

Day $1^{\text {st }}, 3^{\text {rd }}$ and $7^{\text {th }}$
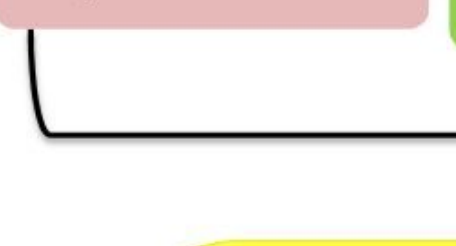
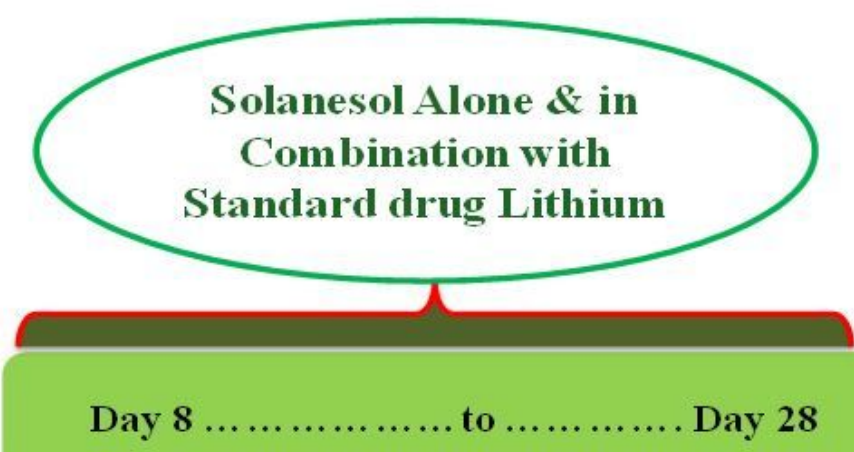

Day $29^{\text {th }}$ to $30^{\text {th }}$

\section{Parameters Performed On Day}

$\checkmark$ Open field test

(day $1,7,14,21,28$ )

$\checkmark$ Locomotor activity

(day $1,9,18,27$ )

$\checkmark$ Force swim test

(day $1,9,18,27$ )

$\checkmark$ Body weight

(day $1,7,14,21,28)$

Figure 1

Experimental protocol schedule (Behavioral \& Biochemical estimations) 


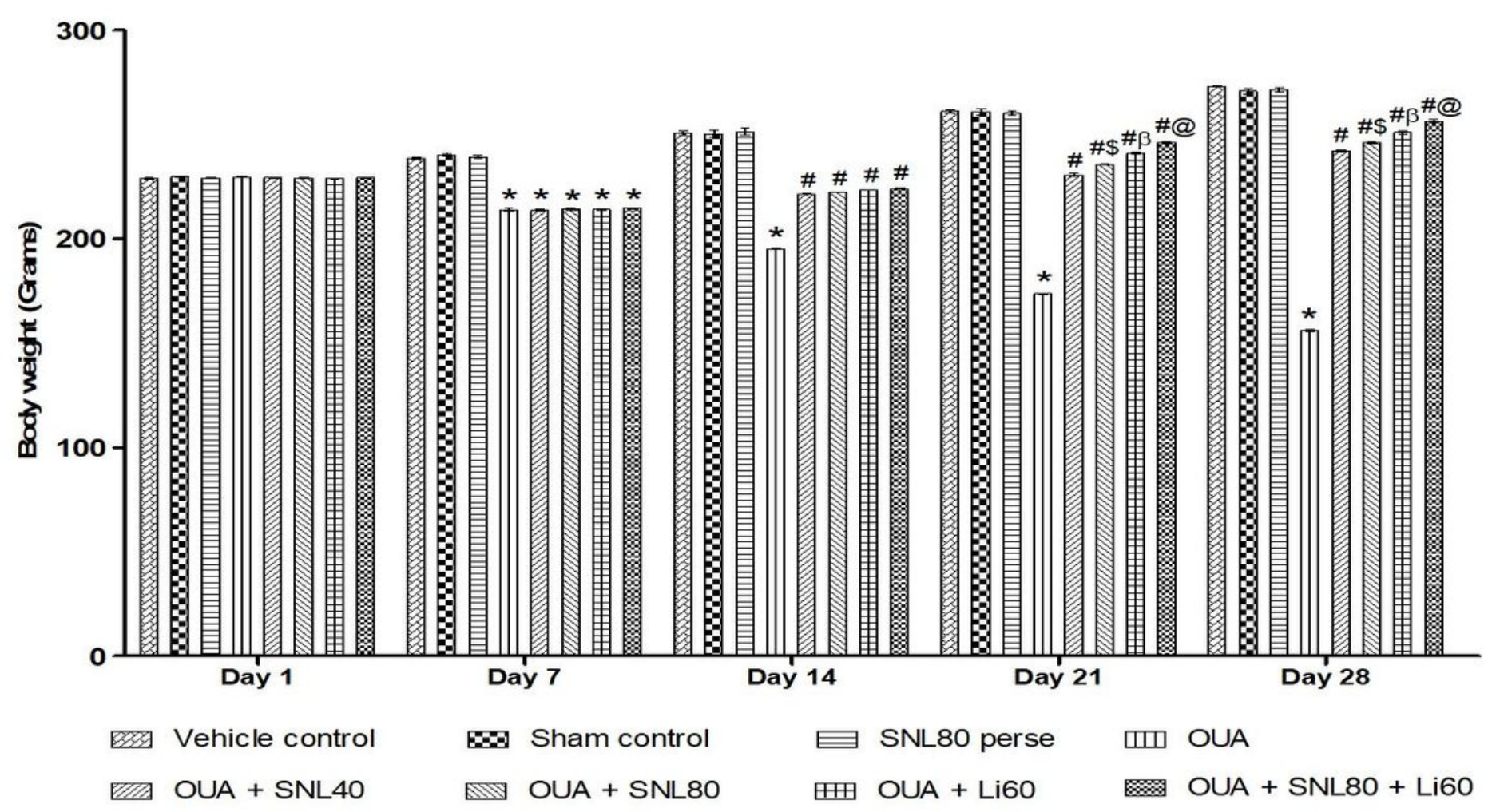

Figure 2

Neuroprotective potential of solanesol on body weight in ouabain-induced bipolar disorder rats Statistical analysis followed by two-way ANOVA (post-hoc Bonferroni's test).Values expressed as mean $\pm S E M(n=6$ rats per group). * $p<0.001 \mathrm{v} / \mathrm{s}$ vehicle control, sham control and SNL80 perse; $\# p<0.001 \mathrm{v} / \mathrm{s}$ OUA; $\# \$$ p $<0.001$ v/s OUA + SNL40; \# p $<0.001$ v/s OUA + SNL40 and OUA + SNL80; \#@ OUA + Li60 

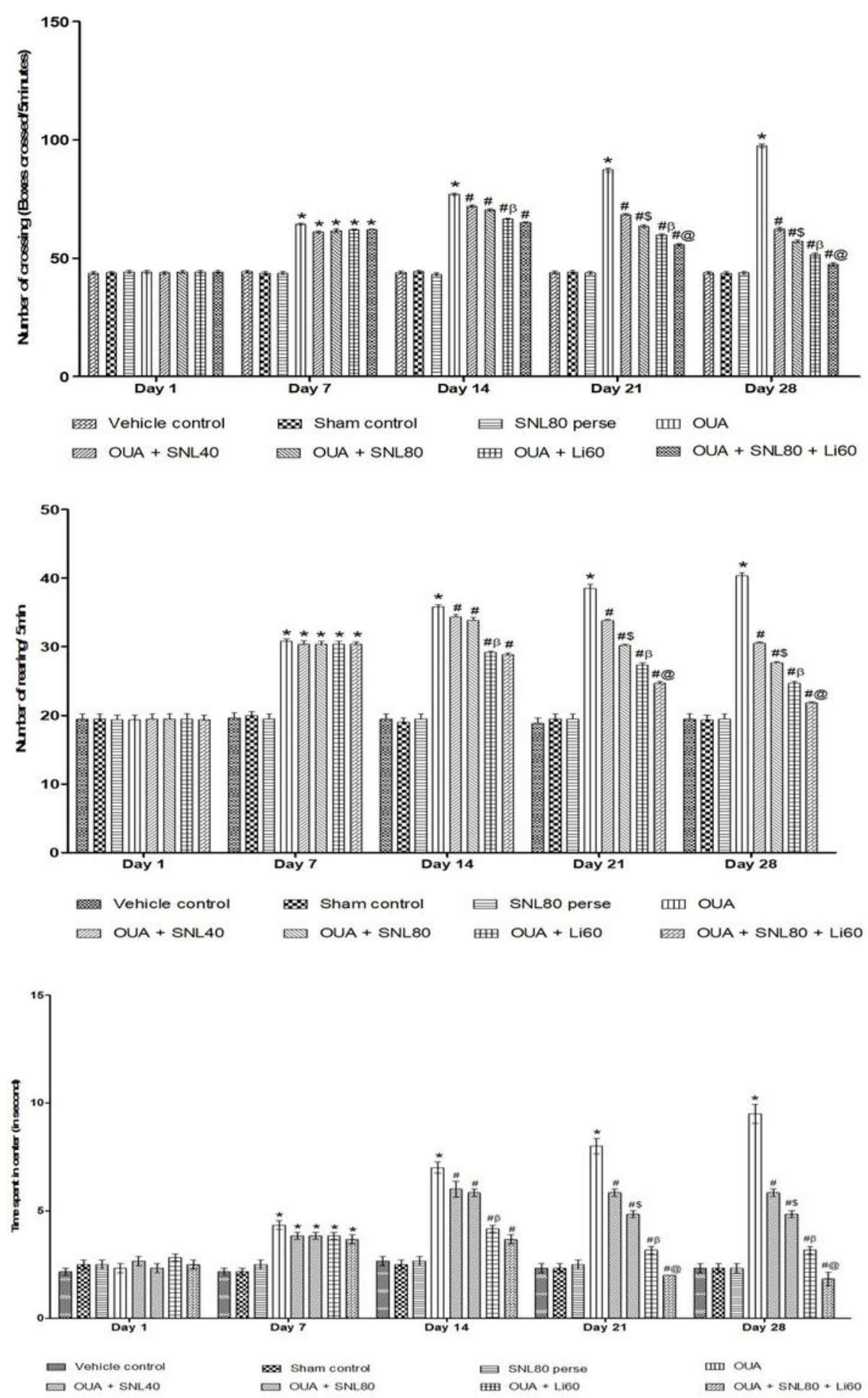

Figure 3

a: Neuroprotective potential of solanesol on Number of crossing in OUA induced bipolar disorder rats Statistical analysis followed by two-way ANOVA (post-hoc Bonferroni's test).Values expressed as mean $\pm S E M(n=6$ rats per group). * $p<0.001 \mathrm{v} / \mathrm{s}$ vehicle control, sham control and SNL80 perse; $\# p<0.001$ v/s OUA; \#\$ p<0.001 v/s OUA + SNL40; \# p < 0.001 v/s OUA + SNL40 and OUA + SNL80; \#@ OUA + Li60. 
Statistical analysis followed by two-way ANOVA (post-hoc Bonferroni's test). Values expressed as mean $\pm S E M(n=6$ rats per group). * $p<0.001 \mathrm{v} / \mathrm{s}$ vehicle control, sham control and SNL80 perse; $\# p<0.001$ v/s OUA; \#\$ p<0.001 v/s OUA + SNL40; \# p p 0.001 v/s OUA + SNL40 and OUA + SNL80; \#@ OUA + Li60. c: Neuroprotective potential of solanesol on in OUA induced bipolar disorder rats Statistical analysis followed by two-way ANOVA (post-hoc Bonferroni's test). Values expressed as mean $\pm S E M(n=6$ rats per group). ${ }^{*} p<0.001 \mathrm{v} / \mathrm{s}$ vehicle control, sham control and SNL80 perse; \# $p<0.001 \mathrm{v} / \mathrm{s}$ OUA; \#\$ $p<0.001 \mathrm{v} / \mathrm{s}$ OUA + SNL40; \# $p<0.001$ v/s OUA + SNL40 and OUA + SNL80; \#@ OUA + Li60.

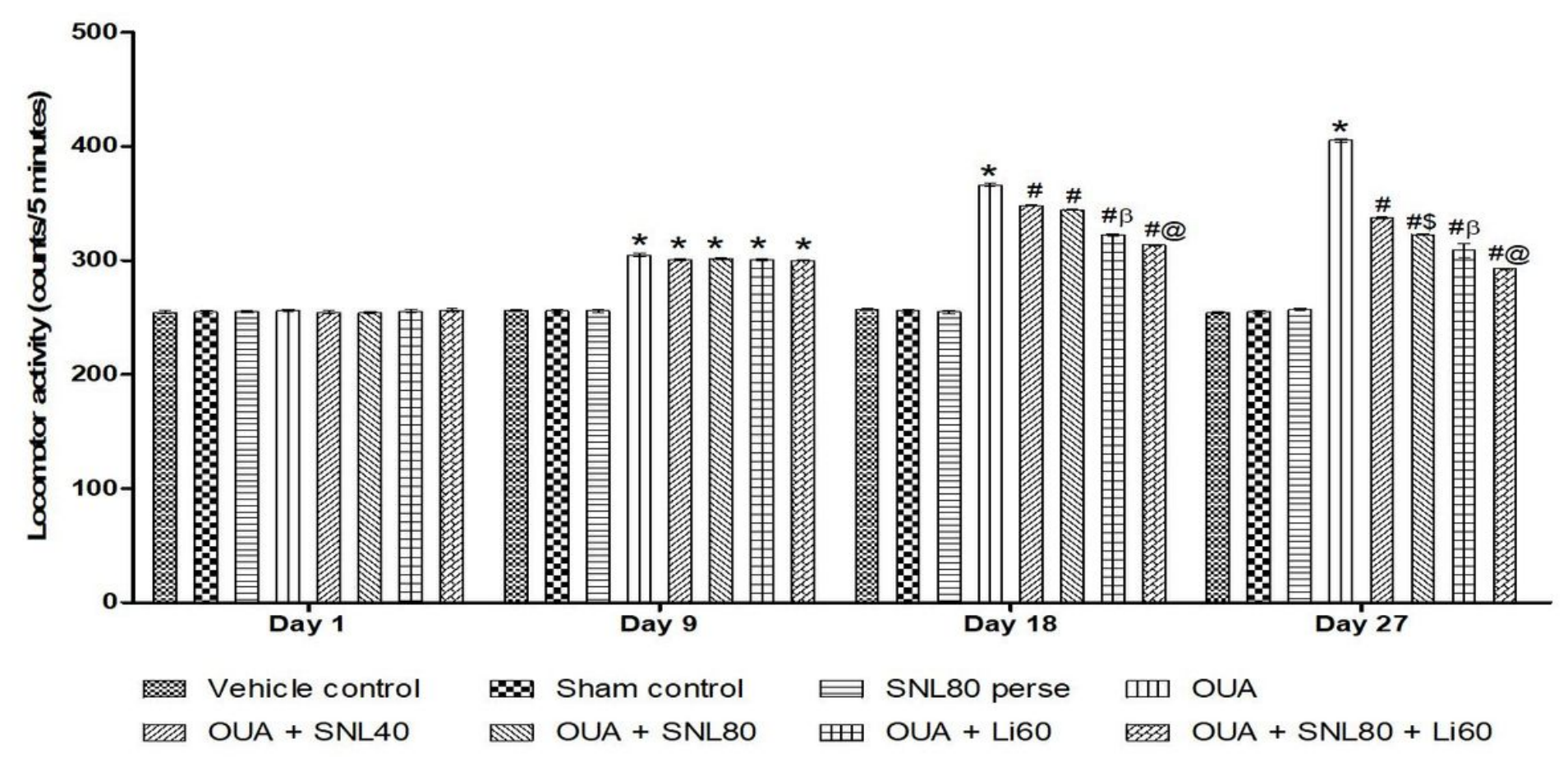

Figure 4

Neuroprotective potential of solanesol on marble buried behavior in OUA induced bipolar disorder rats Statistical analysis followed by two-way ANOVA (post-hoc Bonferroni's test). Values expressed as mean $\pm S E M$ ( $n=6$ rats per group). * $p<0.001 \mathrm{v} / \mathrm{s}$ vehicle control, sham control and SNL80 perse; $\# p<0.001$ v/s OUA; \#\$ p<0.001 v/s OUA + SNL40; \# $\beta$ p<0.001 v/s OUA + SNL40 and OUA + SNL80; \#@p<0.001 v/s OUA + Li60 


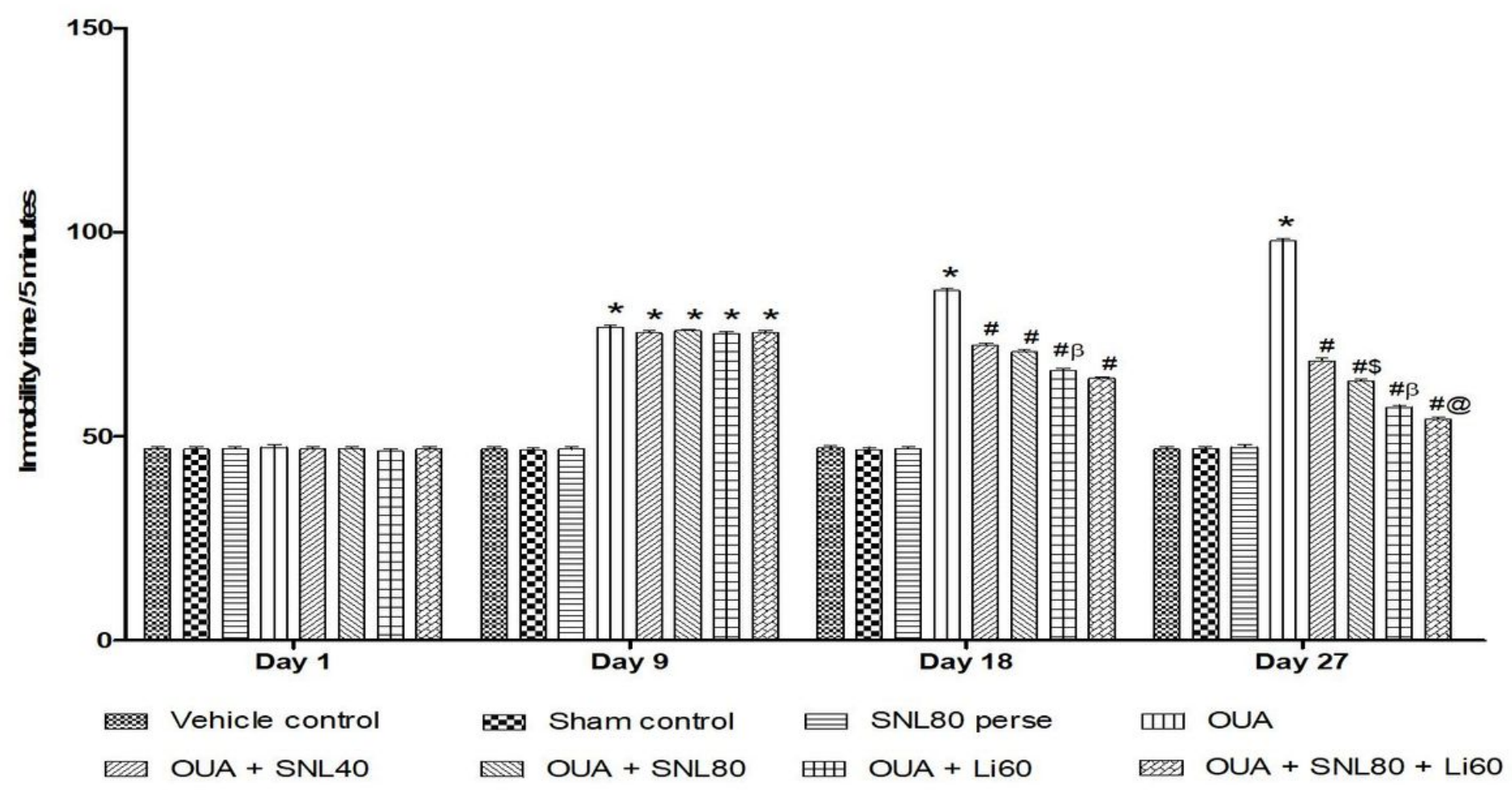

Figure 5

Neuroprotective potential of solanesol on immobility time in OUA-induced bipolar disorder rats Statistical analysis followed by two-way ANOVA (post-hoc Bonferroni's test).Values expressed as mean $\pm \operatorname{SEM}(n=6$ rats per group). * $p<0.001 \mathrm{v} / \mathrm{s}$ vehicle control, sham control and SNL80 perse; $\# p<0.001 \mathrm{v} / \mathrm{s}$ OUA; \# p $<0.001$ v/s OUA + SNL40; \# p <0.001 v/s OUA + SNL40 and OUA + SNL80; \#@ OUA + Li60

\section{Supplementary Files}

This is a list of supplementary files associated with this preprint. Click to download.

- IAECCertificate.pdf

- SUPPLEMENTARYBEHAVIOURALPARAMETERS.XIsX

- SUPPLEMENTARYBLOODPLASMAPARAMETERS.xIsX

- SUPPLEMENTARYBODYWEIGHTPARAMETER.XIsX

- SUPPLEMENTARYBRAINHOMOGENATEPARAMETERS.xIsX

- SUPPLEMENTARYMITOCHONDRIALETCPARAMETERS.XIsX

- SUPPLEMENTARYSIRT1LEVELINCSFBLOODPLASMABRAIN.XIsX 